\title{
Plugs or flood-makers? The unstable landslide dams of eastern
}

\section{Oregon}

Safran, E. B. ${ }^{a}{ }^{*}$, O’Connor, J. E. ${ }^{b}$, Ely, L. L. ${ }^{c}$, House, P. K. ${ }^{d}$, Grant, G. ${ }^{e}$, Harrity, K. ${ }^{f}$,

Croall, K. ${ }^{f}$, Jones, $E^{f}$.

${ }^{a}$ Environmental Studies Program, Lewis \& Clark College, Portland, OR 97219, U.S.A.

${ }^{b}$ U. S. Geological Survey, Geology, Minerals, Energy, and Geophysics Science Center, Portland, OR 97201, U.S.A.

${ }^{\circ}$ Department of Geological Sciences, Central Washington University, Ellensburg, WA 98926, U.S.A.

${ }^{d} U$. S. Geological Survey, Geology, Minerals, Energy, and Geophysics Science Center, Flagstaff, AZ 86001, U.S.A.

e U.S. Forest Service, Pacific Northwest Research Station, Corvallis, OR 97331, U.S.A. ${ }^{f}$ Former address: Lewis \& Clark College, Portland, OR 97219, U.S.A.

${ }^{*}$ Corresponding author. Tel: +1 503768 7690; Fax: +1 503768 7369; Email:

safran@lclark.edu 


\author{
Elizabeth B. Safran (corresponding \\ author) \\ Environmental Studies Program, Lewis \\ $\&$ Clark College \\ MSC 55 \\ 0615 SW Palatine Hill Road \\ Portland, OR 97219 \\ U.S.A. \\ safran@lclark.edu \\ Tel: +1 5037687690 \\ Fax: +1 5037687369 \\ Jim E. O'Connor \\ U. S. Geological Survey \\ 2130 SW $5^{\text {th }}$ Avenue \\ Portland, OR 97201 \\ U.S.A. \\ Lisa L. Ely \\ Department of Geological Sciences \\ Central Washington University \\ Ellensburg, WA 98926 \\ U.S.A. \\ P. Kyle House \\ U. S. Geological Survey \\ Geology and Geophysics Science \\ Center \\ 2255 N. Gemini Drive \\ Flagstaff, AZ 86001 \\ U.S.A.
}

Gordon E. Grant

U.S. Forest Service

Pacific Northwest Research Station

3200 SW Jefferson Way

Corvallis, OR 97331

U.S.A.

Kelsey Harrity

Former address:
Lewis \& Clark College

0615 SW Palatine Hill Road

Portland, OR 97219

Kelsey Croall

Former address:

Lewis \& Clark College

0615 SW Palatine Hill Road

Portland, OR 97219

Emily Jones

Former address:

Lewis \& Clark College

0615 SW Palatine Hill Road

Portland, OR 97219 


\section{Abstract}

1 Landslides into valley bottoms can affect longitudinal profiles of rivers, thereby

2 influencing landscape evolution through base-level changes. Large landslides can

3 hinder river incision by temporarily damming rivers, but catastrophic failure of landslide

4 dams may generate large floods that could promote incision. Dam stability therefore

5 strongly modulates the effects of landslide dams and might be expected to vary among

6 geologic settings. Here, we investigate the morphometry, stability, and effects on

7 adjacent channel profiles of 17 former and current landslide dams in eastern Oregon.

8 Data on landslide dam dimensions, former impoundment size, and longitudinal profile

9 form were obtained from digital elevation data constrained by field observations and

10 aerial imagery; while evidence for catastrophic dam breaching was assessed in the

11 field. The dry, primarily extensional terrain of low-gradient volcanic tablelands and

12 basins contrasts with the tectonically active, mountainous landscapes more commonly

13 associated with large landslides. All but one of the eastern Oregon landslide dams are

14 ancient (likely of order $10^{3}$ to $10^{4}$ years old), and all but one has been breached. The

15 portions of the Oregon landslide dams blocking channels are small relative to the area

16 of their source landslide complexes $\left(0.4-33.6 \mathrm{~km}^{2}\right)$. The multipronged landslides in

17 eastern Oregon produce marginally smaller volume dams but affect much larger

18 channels and impound more water than do landslide dams in mountainous settings. As

19 a result, at least 14 of the $17(82 \%)$ large landslide dams in our study area appear to

20 have failed cataclysmically, producing large downstream floods now marked by boulder

21 outwash, compared to a $40-70 \%$ failure rate for landslide dams in steep mountain 
22 environments. Morphometric indices of landslide dam stability calibrated in other

23 environments were applied to the Oregon dams. Threshold values of the Blockage and

24 Dimensionless Blockage Indices calibrated to worldwide data sets successfully separate

25 dam sites in eastern Oregon that failed catastrophically from those that did not.

26 Accumulated sediments upstream of about $50 \%$ of the dam sites indicate at least short-

27 term persistence of landslide dams prior to eventual failure. Nevertheless, only three

28 landslide dam remnants and one extant dam significantly elevate the modern river

29 profile. We conclude that eastern Oregon's landslide dams are indeed floodmakers, but

30 we lack clear evidence that they form lasting plugs.

32 Keywords: landslides; landslide dams; mass movements; eastern Oregon;

33 geomorphology

34

35 


\section{Introduction}

Rivers propagate climatic and tectonic signals through landscapes, creating local relief and setting the base level to which tributaries and hillslopes respond.

Consequently, the longitudinal profile evolution of mainstem rivers may strongly regulate

41 landscape response to external forcing (e.g., Whipple and Tucker, 1999), particularly in

42 unglaciated landscapes and in landscapes affected by significant rates of uplift or base-

43 level drop. In this conceptual framework, hillslopes are usually cast as responding

44 passively to fluvial drivers. However, recent work has highlighted the ways in which

45 hillslope-channel interactions can modulate local fluvial incision rates over timescales of $4610^{4}-10^{5}$ years (e.g., Hewitt, 1998, 2006; Korup, 2002; Ouimet et al., 2007; Korup et al.,

47 2010; Burchsted et al., 2014). Particular attention has been paid to the effects of large,

48 dam-forming landslides on river morphology and sediment storage over multiple spatial

49 and temporal scales. For example, epicycles of aggradation upstream of landslide dams

50 and incision through the deposits or adjacent bedrock dominate sediment deposition

51 and erosion patterns over $10^{3}-10^{4}$ years in parts of the Himalaya (e.g., Hewitt, 1998;

52 Korup et al., 2006; Hewitt et al., 2008, 2011). A recent modeling study by van Gorp et

53 al. (2014) likewise simulated impacts of landslide damming on sediment storage and

54 release that persist for at least 15,000 years. The lag deposits and sediment wedges

55 associated with long-lived landslide dams can also create persistent knickpoints and

56 associated alluvial plains (e.g., Korup, 2005, 2006, 2011; Schuster, 2006; Ouimet et al.,

57 2007; Walsh et al., 2012), forming prominent morphologic features in some river valleys. 
Landslides can affect the longitudinal profile evolution of rivers in two contrasting

59 manners. Large landslides can inhibit incision locally by altering channel slope, width,

60 and bed character and by burying the valley bottom under landslide material. Dam-

61 forming landslides can also affect reaches upstream from the incursion site because

62 fluvial incision ceases in the dam pool during the lifetime of the dam. If the dam is long-

63 lived, sediment may accumulate in this reservoir, extending the timescale of longitudinal

64 profile recovery until the sediment is evacuated (e.g., Hewitt, 1998). The persistent

65 inhibition of incision in landslide-prone channel reaches, particularly in downstream-

66 most reaches, would tend to produce local to regional convexities in the longitudinal

67 profiles of rivers subject to external forcing (e.g., Ouimet et al, 2007; Safran et al., 68 2008). cataclysmic floods (e.g., Costa and Schuster, 1988; Ermini and Casagli, 2002;

71 O'Connor et al., 2003a, 2013) that have the potential to incise through valley fill or

72 bedrock. These outburst floods can be much larger than meteorologically generated

73 floods and can set the basic architecture of the channel for many thousands of years

74 (Beebee, 2003; O'Connor and Grant, 2003; Schuster, 2006). The incision caused by

75 individual outburst floods from other types of natural dams, such as ice dams, calderas,

76 or tectonic basins, has been well documented (reviewed in O'Connor et al., 2013). Such

77 dams typically impound larger water bodies than landslide dams, with a few notable

78 exceptions (O'Connor et al., 2003a; O'Connor and Beebee, 2009); consequently we

79 expect any enhanced incision during outburst floods from breached landslide dams to

80 be more modest than for other types of outburst floods. However, in environments 
81 where landslide dams are spatially and temporally frequent and susceptible to failure,

82 such effects could potentially be significant, especially where topographic or climatic

83 conditions do not drive high background rates of incision.

$84 \quad$ Not all landslide dams fail catastrophically, however, and the question of whether

85 or not landslide dams may cataclysmically breach has important implications for

86 hillslope-channel coupling and controls on landscape evolution. This issue has been

87 addressed in the context of natural hazards where some assessments of dam stability

88 relate dam size to water available for dam breaching (Casagli and Ermini, 1999; Ermini

89 and Casagli, 2003; Korup, 2004). Threshold values of morphometric functions, or

90 indices, that partially distinguish between stable and unstable landslide dams have been

91 determined for the Italian Apennines (Casagli and Ermini, 1999); for the New Zealand

92 Southern Alps (Korup, 2004); for composite data sets predominantly from Italy, Japan,

93 and the western U.S., with a smattering of examples from the Canadian Cordillera, New

94 Zealand, and elsewhere (Ermini and Casagli, 2003); and for the Argentine Andes

95 (Hermanns et al., 2006, 2011a). Dams that impound extant lakes or ancient lakes that

96 filled with sediment have commonly been classified as stable, although extant lakes still

97 have the potential to drain catastrophically through future dam failure. Costa and

98 Schuster (1991), Hewitt (1998), Ermini and Casagli (2002), and Hermanns et al. (2006,

99 2011a) reported cases of catastrophic failure after hundreds or even thousands of years

100 of dam persistence, e.g., caused by landsliding into existing landslide-dammed lakes

101 and changes in climatic conditions (e.g., Hermanns et al., 2006, 2011a). The unstable

102 landslide dam classification has sometimes been used to denote catastrophic breaching

103 (e.g., Ermini and Casagli, 2003; Hermanns et al., 2011a), but in many instances 
104 breaching occurs in an unspecified manner, and stability classifications are ambiguous 105 (e.g., Korup, 2004; Hermanns et al., 2011a). Here, we do not attempt to designate 106 stable landslide dams but rather focus on whether dams in our study area failed 107 catastrophically or not.

Dam stability analyses have predominantly been applied in rugged, mountainous 109 terrain. However, the propensity for landslide dams to fail catastrophically - - and 110 associated consequences for channels - - likely varies across geologic settings, 111 because of differences in regional physiography, landslide distribution, or landslide type. 112 Some lower-relief environments also exhibit widespread landsliding (e.g., Reneau and 113 Dethier, 1996; Philip and Ritz, 1999; Korup et al., 2007; Safran et al., 2011), but the 114 stability of landslide dams in such settings has not been analyzed.

To address that gap and better understand the formation, failure, and

116 geomorphic consequences of landslide dams in a different environment, we analyze the 117 history and morphometry of 17 ancient landslide dams and their adjacent channels in 118 eastern Oregon. We compare these landslide dam characteristics with two other data 119 sets summarizing landslide dam characteristics from New Zealand (Korup, 2004) and 120 select worldwide sites (Ermini and Casagli, 2003; Korup, 2004). We evaluate field 121 evidence for catastrophic failure, as well as field and map evidence of effects of 122 landsliding on longitudinal river profiles. For each landslide dam, we then compute the 123 value of five stability indices (Blockage index, Dimensionless Blockage index, 124 Impoundment index, Backstow index, Basin index; Ermini and Casagli, 2002, 2003; 125 Korup, 2004). We assess whether any previously published threshold values of these 126 stability indices, derived from other environments, are consistent with our own field 
127 observations relating to dam failure. Our primary aim is to contribute to a more complete 128 picture of the character and behavior of landslide dams by providing data from one of 129 the least tectonically active landscapes likely to support many large landslide 130 complexes, which is important for understanding the diverse potential long-term effects 131 of large landslides on channel and landscape evolution. Our secondary aim is to probe 132 the utility of dam-stability indices and their calibrated failure-threshold values as an 133 interpretive framework for making such comparisons across geologic environments 134 (e.g., Korup, 2004; Hermanns et al., 2006, 2011a).

135

136 2. Study area and dam sites 


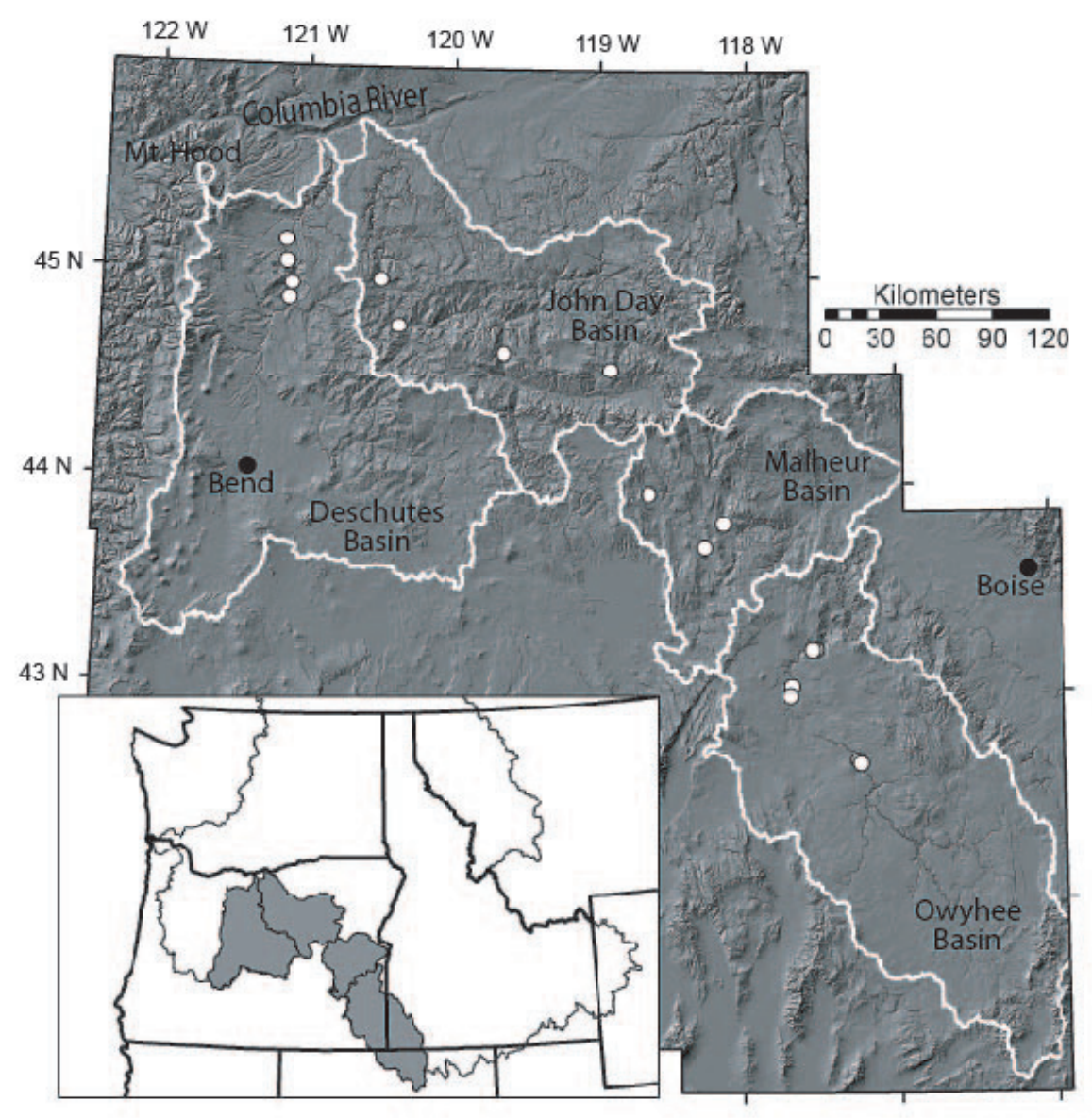

140 Fig. 1. Location map of landslide dam sites analyzed. Thin black outline in inset map depicts 141 Columbia River basin boundary.

142 This semiarid landscape lies in the rain shadow of the Cascade Range and receives on

143 average $25-38 \mathrm{~cm}$ of rain/y, with local maxima of $50-75 \mathrm{~cm} / \mathrm{y}$ in the Ochoco and

144 Strawberry Mountains. The regional geology consists primarily of volcanic and

145 volcaniclastic rocks of Tertiary and Quaternary age. Thick sequences of fluviolacustrine

146 sediments have accumulated since the Miocene in tectonically controlled, largely

147 extensional basins (Cummings, 1991; Christiansen and Yeats, 1992; Cummings et al., 148 2000). Igneous deposits ranging in composition from rhyolitic ash flow tuffs and 
149 calderas to basaltic lava flows form low-gradient plateau tops punctuated by higher-

150 standing peaks. The region stands at an elevation of $>1 \mathrm{~km}$ above mean sea level

151 (amsl), rising to an average surface elevation of almost $1.4 \mathrm{~km}$ amsl near the shared

152 borders of Oregon, Idaho, and Nevada (Camp and Ross, 2004). The uplifted plateaus

153 are dissected by canyons cut by major rivers, creating corridors where local relief

154 reaches a few $100 \mathrm{~m}$ (Fig. 2).

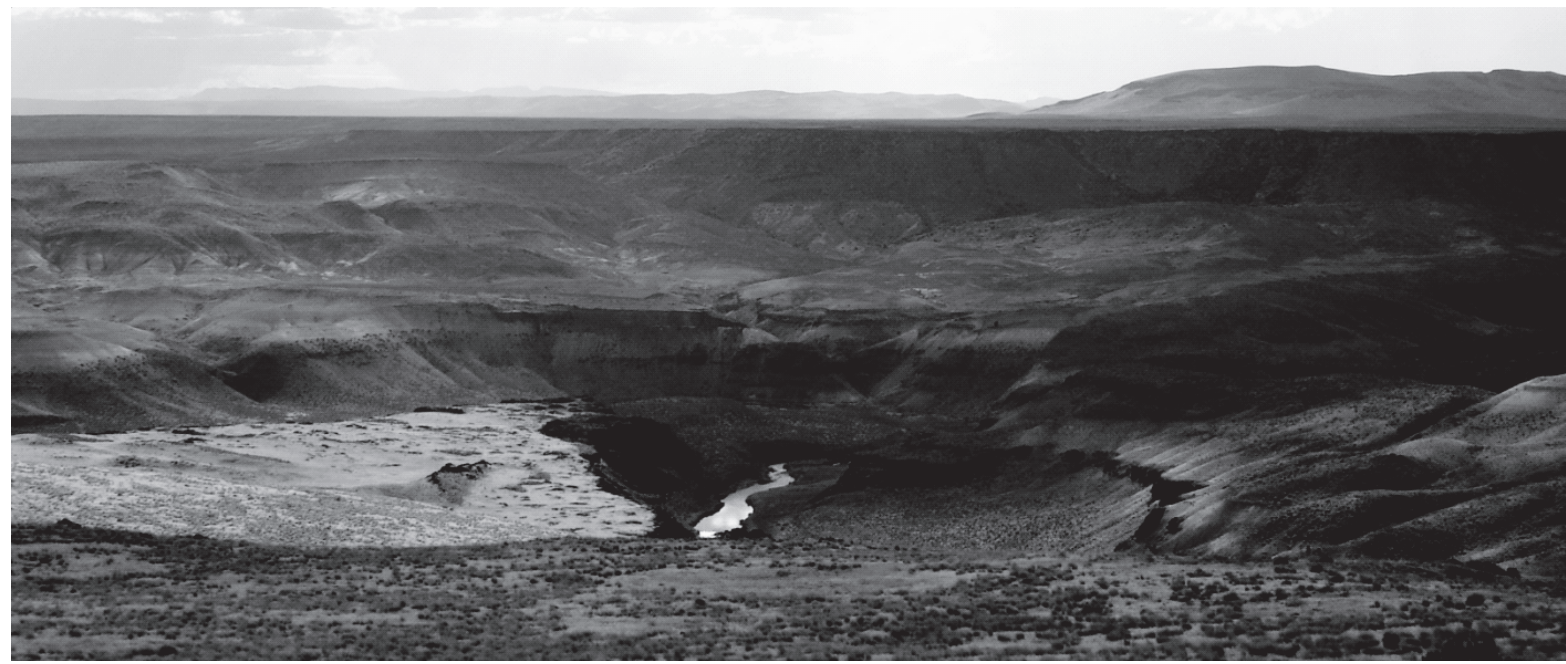

Fig. 2. View of Owyhee River illustrating typical regional landscape morphology. Tertiary and Quaternary lava flows form plateaus at multiple elevations, and incising river canyons create local relief of several $100 \mathrm{~m}$.

Most large rivers in this region drain to either the Snake or Columbia rivers. Modest

160 local relief was likely already established in the mid- to late-Pliocene, in part caused by

capture of the Snake River by the Columbia River 3-4 Ma (Repenning et al., 1995; Van

162 Tassell et al., 2001) and in part because of other, incompletely understood drivers.

163 Average incision rates on the Deschutes River, a tributary of the Columbia River, were

164 about $0.1 \mathrm{~mm} / \mathrm{y}$ between $\sim 4$ and $1 \mathrm{Ma}$, when the river reached its near-present level

165 (O'Connor et al., 2003b). In the last $2 \mathrm{Ma}$, long-term incision rates on the Owyhee

166 River (a tributary to the Snake River) between Rome and Birch Creek have been $\sim 0.2$ 
$167 \mathrm{~mm} / \mathrm{y}$ (Ely et al., 2012). Although the regional drainage pattern was broadly established 168 by middle Miocene to early Pliocene times (Smith, 1986; Beranek et al., 2006), the combination of low precipitation rates, low regional gradients, and tectonic and volcanic 170 disruption of drainage networks has led to poor hydrologic integration. Nearly 60,000 $171 \mathrm{~km}^{2}$ of eastern Oregon is presently internally drained, although portions of those areas 172 were integrated during wetter climatic times (Carter et al., 2006). Large landslide complexes, some larger than $30 \mathrm{~km}^{2}$, are widespread throughout 174 the region (Safran et al., 2011). Their distribution is preferentially associated with 175 escarpments where coherent volcanic rock units overlie weak, volcaniclastic debris with 176 several tens to hundreds of meters of local relief (Safran et al., 2011). The spatial 177 density of mapped faults exerts no control on landslide distribution, while about $10 \%$ of 178 landslides occur within 3-10 km of mapped fold axes (Safran et al., 2011). Most of the > 179400 landslides that have been mapped throughout the region are multiple rotational 180 slides, but $\sim 5-10 \%$ are earth flows, debris flows, and lateral spreads (Safran et al., 181 2011). Geochronologic constraints are weak and are available for only $\sim 5$ of mapped 182 complexes, but they indicate that some are at least as young as early Holocene age, 183 while most are likely Pleistocene (Safran et al., 2011). The age of the landslides and the 184 lack of spatial association with faults suggests that triggers may have been climatic, 185 primarily restricted to periods of greater moisture availability. Although precipitation 186 rates at the last glacial maximum were likely approximately the same as today's (Oster 187 et al., 2015), reduced evaporation rates led to the formation of lakes in some of the 188 closed basins of eastern Oregon and the Great Basin (Ibarra et al., 2014), suggesting a 
net increase in terrestrial moisture. These conditions could have promoted landsliding 190 during the Pleistocene.

Many landslides in eastern Oregon are known or are strongly suspected to have

192 blocked rivers in the past (Beebee, 2003; O'Connor et al., 2003a; Othus, 2008; Safran

193 et al., 2011), but we are aware of only one landslide in the region that still impounds a

194 lake. All other blockages have been breached. A similar situation was faced by

195 Hermanns et al. (2006) in the NW Argentinian Andes; but in other regions where

196 landslide dams have been studied, samples of intact and of breached landslide dams

197 exist (Casagli and Ermini, 1999; Ermini and Casagli, 2003; Korup, 2004; Hermanns et

198 al., 2011a). In eastern Oregon, we relied on field observations of dam remnants and the

199 surrounding channel reaches to assess evidence for catastrophic breaching or

200 persistence.

201 The landslide sites selected for the present study constitute only a small subset

202 of mapped landslides that may have blocked the region's rivers. The sites were selected

203 because of clear evidence for channel blockage and/or good preservation of the

204 morphology of the landslide dam. Several sites from each major drainage basin were

205 selected, and the sites represent the diversity of landslide types in the region (Table 1).

206 We have made field visits to all but three of the dam sites. Some form of

207 geochronologic constraint on the age of the landslides, landslide dams, or outburst

208 floods exist for almost half of the sites, described below.

209

210 3. Geochronologic constraints on landslide dams 
Most geochronologic information about the eastern Oregon landslide dams is

212 indirect and relates either to the landslides or to associated outburst floods; dated

213 sediment accumulations upstream of landslide dams are rare. In the Deschutes River

214 basin, age constraints on the Whitehorse landslide dam are weak; the slide occurred

215 sometime between $38,740 \pm 540{ }^{14} \mathrm{C}$ YBP and the 7.7 ka Mazama eruption (O'Connor et

216 al., 2003a). Sediments inferred to have been deposited in an impoundment upstream of

217 the Dant debris flow contain pumice granules similar to ones from the same area dated

218 at 0.40-0.46 Ma (O'Connor et al., 2003a). Auger holes dug into sediments collected in

219 closed depressions on the Wapinitia landslide and the morphologically fresher-looking

220 Boxcar landslide downstream indicate the presence of the 7.7 ka Mt. Mazama ash. The

221 ash is at the base of the sediments on the Boxcar landslide and close to, but not at, the

222 base of the sediments on the Wapinitia landslide, consistent with the relative age

223 assessment based on morphology. In the John Day River basin, the Magone Lake site

224 affords the only direct indication of time of dam formation, supposedly in the late 1800 s

225 (Mosgrove, 1980). Mazama ash was found in a closed depression on the Burnt Ranch

226 landslide toe, implying that this landslide also pre-dates the Mazama eruption. In the

227 Malheur River basin, widespread tephra from the Mt. Mazama eruption of $7.7 \mathrm{ka}$ is

228 absent in the prominent bank cuts in sediment accumulations upstream of the Chukar

229 Park site, suggesting a post-Mazama age for the landslide blockage. In the Owyhee

230 River basin, the most recent blockage of the river in the reach of the Artillery landslide

231 complex was most likely between $28 \pm 2$ and $18 \pm 1 \mathrm{ka}$, based on ${ }^{3} \mathrm{He}$ cosmogenic

232 radionuclide (CRN) ages of outburst flood boulders directly downstream. The age of the

233 East Springs Greeley earth flow is not well constrained. Mazama tephra (7.7 ka) was 
234 found in a closed depression on the large boulder bar immediately downstream, which 235 could be an outburst flood deposit from this earth flow blockage. Two ${ }^{3} \mathrm{He}$ CRN samples 236 yielded ages of $354 \pm 25 \mathrm{ka}$ on the uppermost portion of the boulder bar and $14 \pm 1 \mathrm{ka}$ on 237 a lower portion. Based on the landslide's well-preserved morphology, the age is most 238 likely closer to the younger end of this range. No geochronologic information exists for 239 the Hogsback site, but morphologically it is one of the most rugged landslides along the 240 Owyhee corridor. Based on comparison with other landslides along this river for which

241 we do have some age information (Safran et al., 2011), it is likely less than than $\sim 10 \mathrm{ka}$.

\section{4. Dam and reservoir morphometry}

244 4.1. Methods

As noted by Korup (2004), acquisition of morphometric data for landslide dams is

246 a difficult task that includes many subjective judgments. Methodological detail about

247 these judgments is often lacking in the literature, hindering comparisons among studies.

248 Therefore, only major differences among landslide dam populations documented by

249 different researchers are likely to be credible. Here we describe how we determined the

250 values of seven parameters that are either reported as summary statistics of other

251 landslide-dam samples or used to compute various dam stability indices (Ermini and

252 Casagli, 2002, 2003; Korup, 2004). We also describe the collection of longitudinal

253 profile data used to assess the long-term effects of the landslide dams.

$254 \quad$ Former channel blockages were identified using one or more key criteria, which 255 were assessed either in the field, remotely, or both. Criteria included: (i observation of 256 an individual landslide deposit on both sides of the present-day stream (e.g., Fig. 3A); (ii 257 highly constricted and/or laterally displaced river reaches (e.g., Fig. 3B); (iii presence of 
rapids in the constricted reach, suggesting a lag deposit; (iv terraces upstream of potential blockages at or below the probable dam height, suggesting sediment accumulation within the impoundment; or (v outburst deposits downstream of the blockage, such as boulder bars or flood-swept boulders

262 on elevated surfaces. Remote assessments of these features were made using Google Earth imagery, 1-m resolution color orthophoto quarter quadrangles of National and where available (for reaches of the Owyhee and Deschutes rivers), higher-

resolution DEMs derived

270 from lidar data.
Fig. 3. Example indicators of former channel blockages.

(A) Landslide deposits that span the present-day channel. At the Artillery site on the Owyhee River, the Saddle Butte lava flow is in place only on the western (left) side of the river.

However, large blocks of Saddle Butte lava involved in a complex rotational failure are found on both sides of the river, indicating that the landslide deposit must have previously blocked the river. Rafters in center of photo for
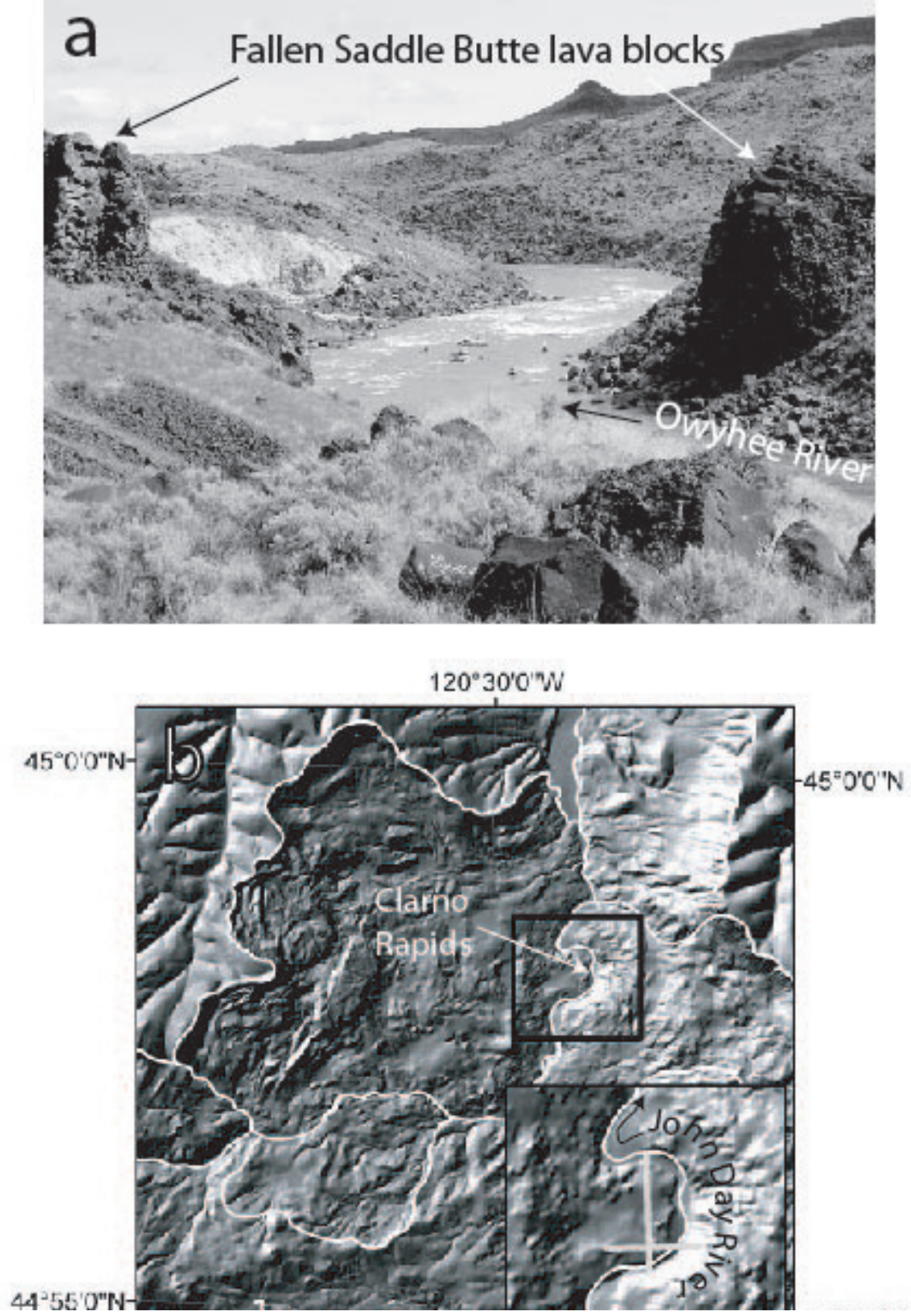
scale. (B) Sharp local deflections of the basal stream. A finger of material $\sim 0.6 \mathrm{~km}^{2}$ within the

For each landslide dam, we identified a critical site cross section and the breach zone

standard though the convention is confusing: that landslide dam width is defined in the

along-channel direction and dam length $\left(L_{D}\right)$ is defined in the cross-channel direction;

333 (supplementary Data Repository items 1 and 2); examples are shown in Fig. 4.

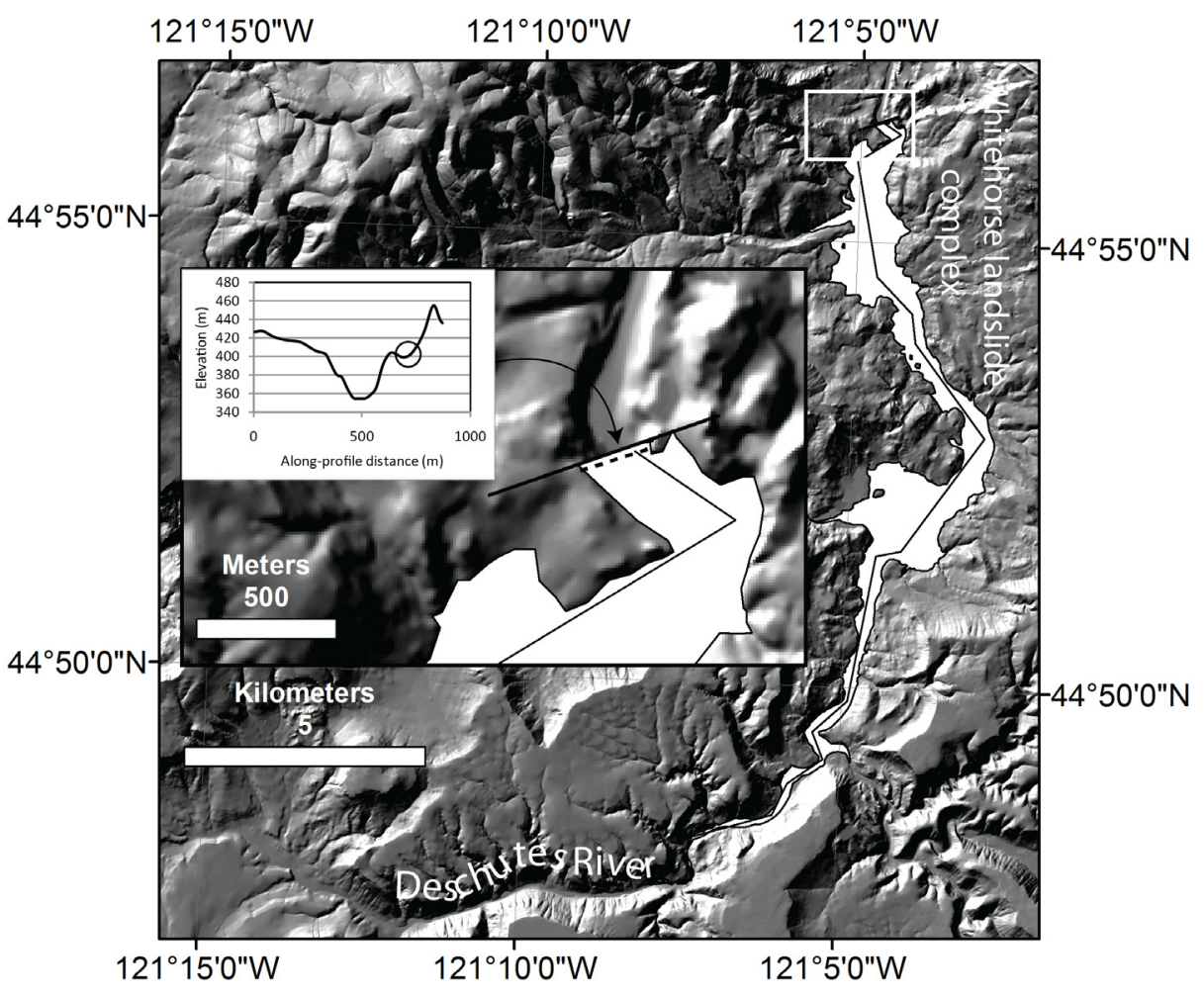

Fig. 4. Illustration of GIS features used to characterize landslide dam and impoundment 
the reservoir impoundment associated with landslide dam height determined by identifying minimum alternative spillover elevation (section 4.1). Solid line along reservoir was used to determine reservoir length. Inset shows close-up of dam site and valley cross section at the dam location indicated by the solid black line on the main map. Elevation and location of alternative minimum spillover route circled on cross-sectional profile. Dashed line indicates dam length used in morphometric analyses. sediment deposits (Dant); or in the majority of cases, as the elevation of the minimum alternative spillover (MAS) route (Fig. 4). The MAS defines the location along the critical cross section where water impounded behind the dam would have spilled if it had not carved down at the present channel location. It represents a local elevation minimum, apart from the present channel, along the critical section. The elevation of the MAS therefore represents a maximum possible landslide dam height. landforms: channel constrictions, rapids, or the start or end points of outburst flood bars or upstream sediment accumulations, respectively. The length of the landslide dam $\left(L_{D}\right)$ across the channel was more difficult to identify, particularly at locations where there were multiple landslide complexes on both sides of the present channel (e.g., Fig. 3B).

361 In such cases, the blocking sections of the landslides do not appear as distinct

362 invasions of a well-defined valley floor, such as those formed by rock avalanches in 363 steep mountain valleys. The valley walls themselves are landslide masses, and the 
channel weaves its way among and through the failed blocks. For this reason, we defined the across-channel length of the dam as the length of failure mass in contact with the reservoir impounded by the chosen dam height at the critical dam cross section

367 (see below; Fig. 4). This is the across-channel extent of material that was involved in 368 holding back the water impounded by the dam.

The volume and length of the lake ( $V_{L}$ and $L_{L}$, respectively) impounded by a 370 landslide dam were determined as follows. Once $H_{D}$ was identified and the critical dam

371 cross section located, a smaller DEM extending upstream from the dam site and up the 372 valley walls from the blocked channel was extracted from the base DEM. A raster data 373 set delineating elevations less than or equal to that of $H_{D}$ was determined from this 374 smaller DEM. This data set defined the planview pattern of the reservoir that would 375 have formed behind the dam (Fig. 4). Care was taken to ensure that the smaller DEM 376 neither cut off places to which the reservoir would have otherwise extended nor 377 included water bodies separate from the reservoir. A line was digitized along the 378 generalized path of the reservoir to define the length of the lake (Fig. 4; supplementary 379 Data Repository item 3). The volume of the reservoir was computed using the Area and 380 Volume tool in 3D Analyst of ESRI ArcGIS. The $H_{D}$ was used as the threshold elevation, 381 and the volume beneath that plane was computed using the small DEM. This method by 382 necessity assumes that the modern topography existed at the time that the landslide 383 dam was emplaced. Computed volumes could be underestimates if significant 384 sedimentation occurred in the valley while or after the dam was in place. Computed 385 volumes could also be overestimates if large landslides developed subsequent to the 386 dam, broadening the valley and creating more space for impounded water than existed 
during the dam's lifetime. Present geochronologic constraints do not permit us to resolve these ambiguities. Five of the 17 sites exhibit no or minimal landslide-affected terrain in what would have been the impoundment zone upstream of the dam site: six 390 have moderate amounts, and six have significant amounts. Based on visual estimates 391 of how much terrain might have been affected by changes in accommodation space, we 392 judge maximum errors on our lake volume estimates to be approximately $\pm 50 \%$. dams required finding the drainage area of the channels at the blockage sites. This was determined using standard tools in ArcGIS by computing a flow accumulation raster derived from a 30-m DEM mosaic extracted to the modern drainage basin boundaries. We estimate likely errors associated with these measurements as $<5 \%$. required determining landslide dam volume, $V_{D}$. Dam volume was estimated by multiplying along-channel width by across-channel length by dam height $\left(W_{D} \times L_{D} \times H_{D}\right)$.

401 Because virtually all landslide dams are breached and now form part of the through402 flowing channel's valley wall, most landslides have been thinned by erosion, reducing 403 the observed vertical thickness. It is therefore difficult to estimate landslide dam 404 thickness from the elevations of the terrain constituting the dam remnant. The $H_{D}--$ the 405 landslide height at the critical cross sections - - was considered the most repeatable and 406 consistent metric of the dam's vertical dimension. We used a second method to analyze 407 dam thickness for comparison with the $H_{D}$ estimate by considering four of the dams with 408 distinct and easily defined planform dimensions (Dant, Warm Springs River, Burnt 409 Ranch, and Clarno). We determined the mean elevation of channel pixels on the 10-m 
410 DEM through the reach of breached landslide. We then determined the median and

411 75th percentile elevations in the dam remnant, reasoning that the lower elevations in the

412 dam remnant reflect the effects of post-dam erosion. We subtracted the mean channel

413 elevation from the 50th and 75th percentile elevations to get two estimates of landslide

414 dam thickness for each dam. For all four sites, both these estimates of landslide dam

415 thickness were within $25 \%$ of $H_{D}$. In three of the four cases, $H_{D}$ equaled or exceeded the 416 other two thickness estimates. Overall, we estimate landslide dam height errors to be 417 around $\pm 25 \%$ and landslide dam volume errors to be at least $\pm 50 \%$.

418 To assess the morphologic effects of the landslide dams on the longitudinal 419 profiles of the adjacent streams, we used the best available elevation data to extract the 420 elevation values of points along an $\sim 10-30 \mathrm{~km}$ channel reach bracketing each dam site. 421 For the Heaven's Gate, Artillery, West Springs Greeley, and East Springs Greeley sites 422 on the Owyhee River, longitudinal profiles were extracted from a 1-m-resolution DEM 423 based on lidar data. The channel centerline was digitized at a scale of 1:5000, based on 424 lidar hillshades and NAIP orthophotographs. Points were constructed every $50 \mathrm{~m}$ along 425 the centerline, and along-stream distances were computed for each point. Elevation 426 values of the lidar DEM were extracted to the points. For the Whitehorse, Dant, and 427 Wapinitia sites on the Deschutes River, a similar process was followed using DEMs 428 derived from 2-m-resolution lidar data, with points constructed every $100 \mathrm{~m}$ along the 429 channel centerline. For the Magone Lake (John Day basin) and Wolf Creek (Malheur 430 basin) reaches, longitudinal profiles were extracted from 10-m-resolution National 431 Elevation Data DEMs using the ArcHydro Tools add-in to ArcGIS 10. For the Warm 432 Springs River reach (Deschutes basin); Sheep Rock, Burnt Ranch, and Clarno reaches 
433 (John Day basin); Hogsback, Deary Pasture reaches (Owyhee basin); and Chukar Park 434 and Warm Springs Reservoir reaches (Malheur basin), profiles extracted from the DEM 435 using automated routines produced topographic steps that were artifacts of the DEM.

436 We therefore constructed longitudinal profiles for these reaches from contour-line 437 intersections with the rivers as depicted on USGS 7.5-minute topographic quadrangles.

438 Reach segments were chosen to straddle the landslide dam locations and to include 439 enough elevation data to capture the form of the local profile; along-reach distance was 440 determined relative to these boundaries. Benchmark and noted survey elevations were 441 also included where appropriate. Six to eleven contour crossings or surveyed elevations 442 were used for longitudinal profiles extracted manually. For all reaches, points falling 443 within the breach zone of each dam site were identified in ArcGIS and marked on the 444 longitudinal profiles.

445

$446 \quad$ 4.2. Results 
448 those in other parts of the world in several ways.

449 Landslide dams are comparable in size or smaller in

450 Oregon. Mean dam height $\left(H_{D}\right)$ is $50 \%$ lower for eastern

451 Oregon dams than for New Zealand or worldwide dams,

452 and dam volume $\left(V_{D}\right)$ is an order of magnitude lower (Fig.

453 5). However, the contrast is not so great considering

454 median values; median $H_{D}$ values in Oregon are only 20-

$45530 \%$ lower than elsewhere - - a difference that is probably

456 not significant - - and median dam volumes are

457 comparable (Fig. 5).

458 Fig. 5: Comparison of geomorphometric characteristics of 459 eastern Oregon landslide dams with data sets from New 460 Zealand and a worldwide compilation. New Zealand data are 461 from Korup (2004). Drainage areas for worldwide data are from 462 Ermini and Casagli (2003); other statistics for worldwide data 463 are extracted from Korup (2004). Solid black squares are 464 median values; gray circles are mean values. Standard errors 465 on the mean are plotted. Number of dams used for statistics 466 are 16-17 for eastern Oregon, 49-202 for New Zealand, and 467 83-148 for worldwide data (i.e., not all quantities were 468 measurable or reported for each dam). Note logarithmic axes 469 on dam volume, lake volume, and drainage area plots.

470

471 potential for producing outburst floods is that the median

472 (though not mean) impounded lake volume is larger for

473 eastern Oregon, despite similar or smaller landslide dam

474 volumes (Fig. 5). Mean lake length is $50 \%$ greater in

475 eastern Oregon than worldwide, and an order of

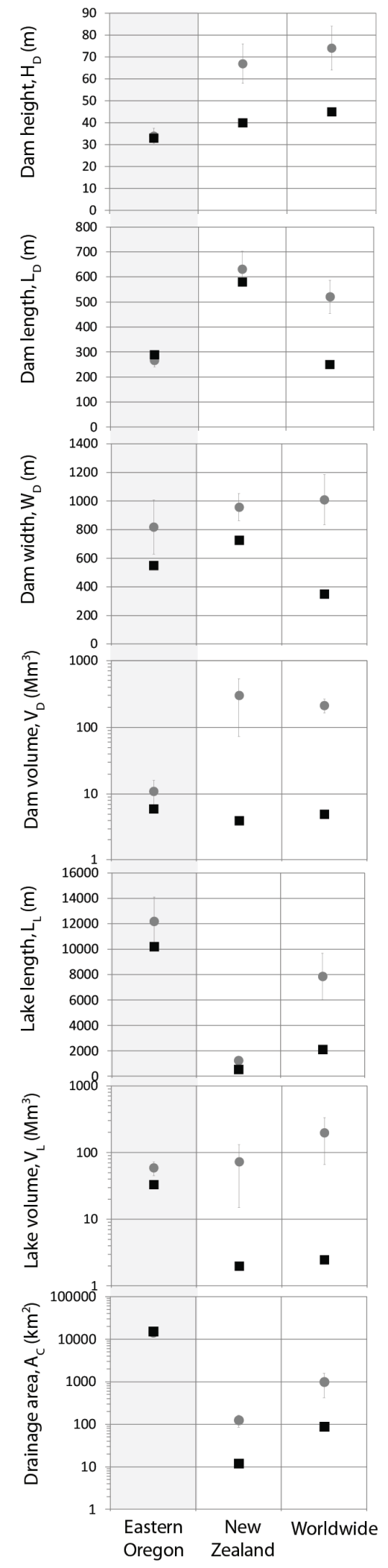


476 magnitude greater than in New Zealand. The differences between eastern Oregon and 477 worldwide data are even more pronounced (500\% vs. $50 \%)$ when considering median 478 lake length.

$479 \quad$ The large volumes of the impounded lakes in eastern Oregon in part results from 480 the larger drainage areas of channels blocked by landslide dams in our study area 481 compared to other areas. These rivers with relatively large upstream drainage areas 482 have lower gradients, so the landslides impound water much farther upstream. The 483 mean and median drainage areas are, respectively, one and two orders of magnitude 484 larger for our landslide dams than for landslide dams worldwide (Fig. 5). The mean and 485 median drainage areas are, respectively, two and three orders of magnitude larger for 486 our landslide dams than for New Zealand landslide dams (Fig. 5).

488 channel and dam volume. Dam volume spans three orders of magnitude (order $10^{5}-10^{8}$ ) 489 on streams with drainage areas $<5000 \mathrm{~km}^{2}$, but variability in dam volumes on rivers 490 with drainage areas $>5000 \mathrm{~km}^{2}$ is confined to about one order of magnitude (Fig. 6).

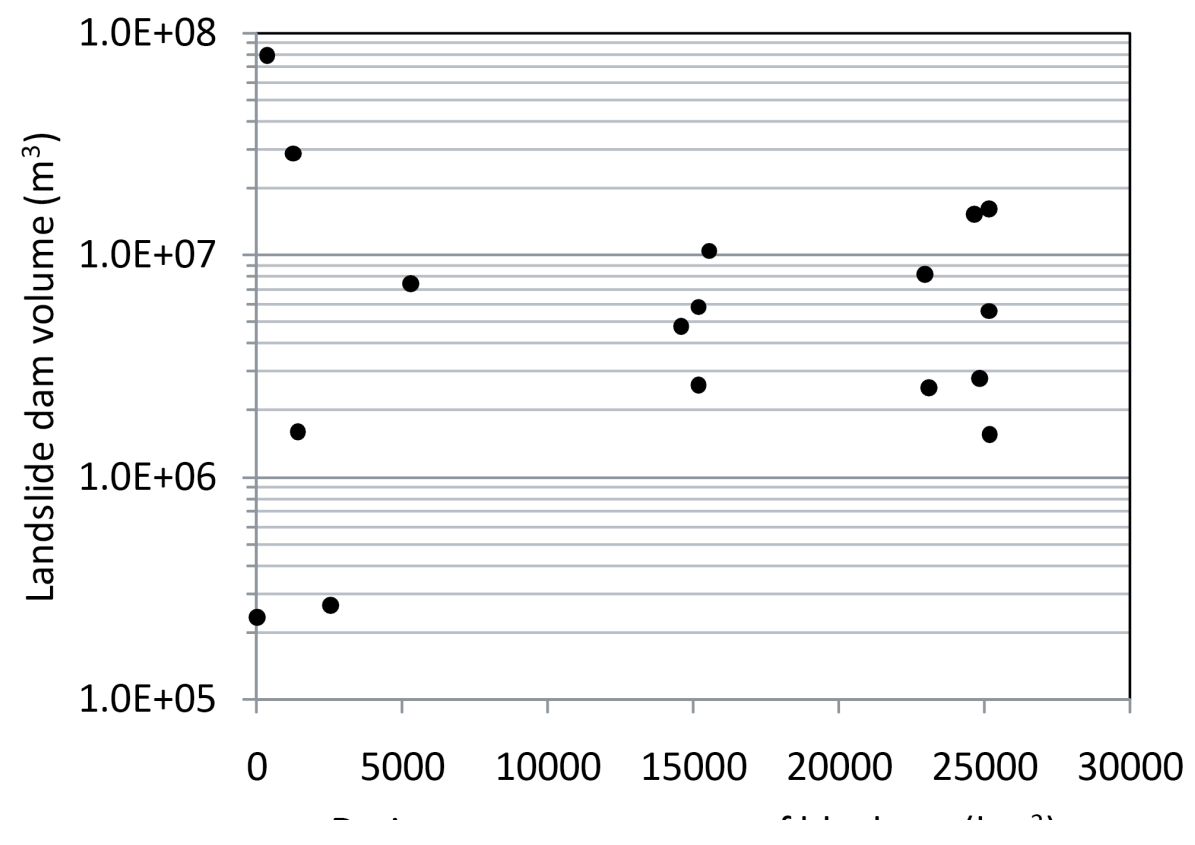

Fig. 6. Landslide dam volume plotted against drainage area upstream of blockage. 
504 dams formed, the baseline gradients of the affected reaches vary widely. To highlight

505 topographic anomalies associated with landslide dams, we plotted longitudinal profiles

506 normalized by total elevation drop and total distance along each reach (Fig. 7A) in

507 addition to showing traditional longitudinal profiles (Fig. 7B). The longitudinal profiles of

508 the stream reaches adjacent to the landslide dams are generally relatively linear (Fig.

509 7). Exceptions are the Chukar Park, Hogsback, Magone Lake, and Whitehorse dam

510 sites, which are all at the downstream end of convexities that are several meters to

511 several tens of meters high and extend over several hundreds of meters to several

512 kilometers. The remaining dam sites have no systematic relationship to broad-scale

513 profile irregularities, although most have rapids at or near the landslide dam sites. 

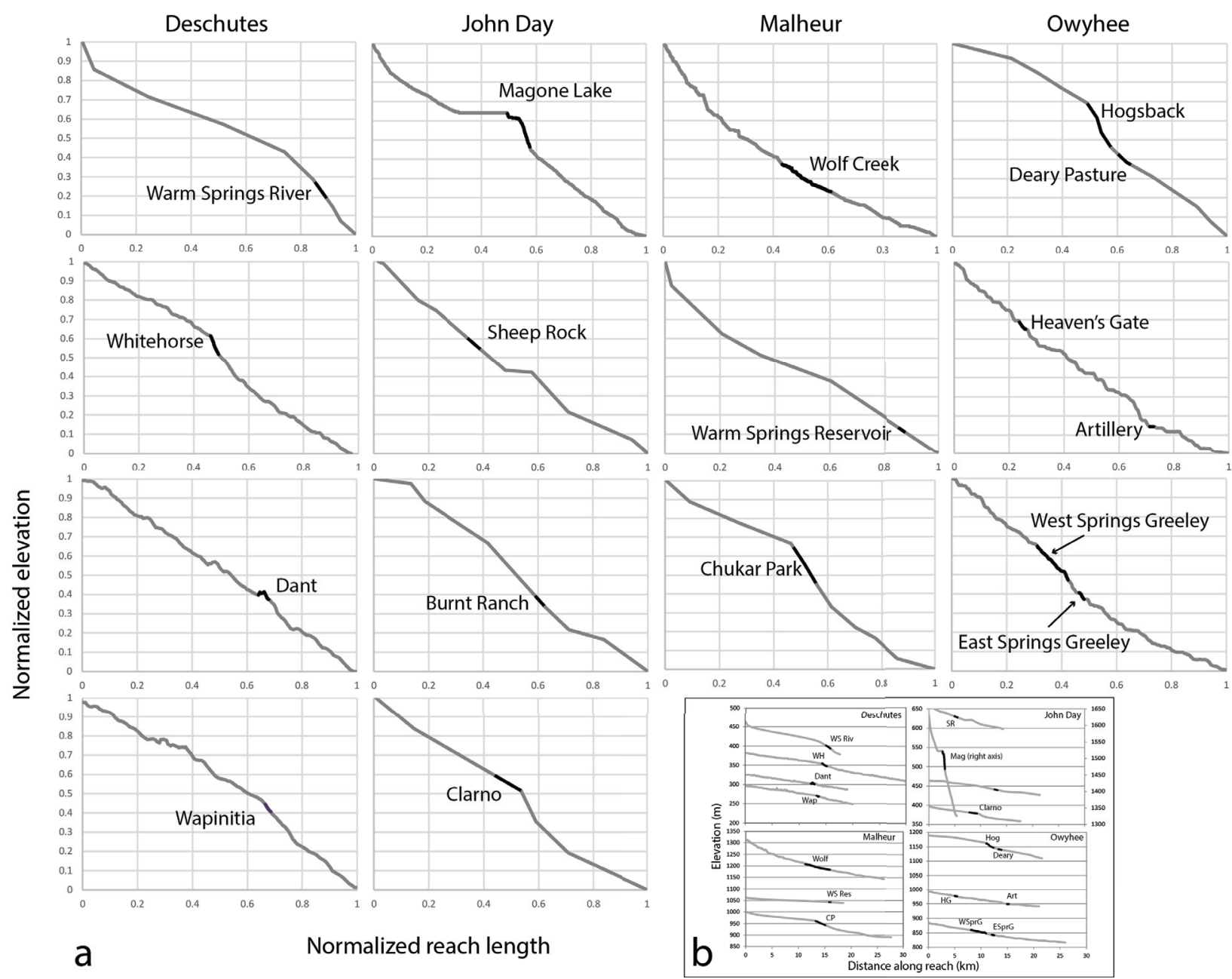

Fig. 7. Longitudinal profiles of stream reaches straddling landslide dam study sites. Black lines indicate segments of the profiles that cut through landslide dams. Profiles containing Whitehorse, Dant, Wapinitia, Heaven's Gate, Artillery, West Springs, and East Springs sites are derived from lidar data; profiles containing Magone Lake and Wolf Creek were extracted from National Elevation Data set 10-m DEMs; all other profiles were constructed from points where contours on 1:24,000 USGS digital topographic quadrangles crossed the study stream reaches. See section 4.1 for details. (A) Profiles normalized by total elevation drop and distance along reach. (B) Standard longitudinal profiles. Note the dual y-axes on John Day graph: Right-hand axis pertains to Magone Lake profile; left-hand axis pertains to all other profiles. Abbreviations: WS Riv = Warm Springs River; WH = Whitehorse; Wap = Wapinitia; SR = Sheep Rock; Mag = Magone Lake; Wolf = Wolf Creek; WS Res = Warm Springs Reservoir; CP = Chukar Park; Hog = Hogsback; Deary = Deary Pasture; HG = Heaven's Gate; Art = Artillery; WSprgG = West Spring Greeley; ESprgG = East Spring Greeley.

\section{Landslide dam stability indices}


533 (2004): Blockage index $\left(I_{b}=\log \left(V_{D} / A_{C}\right)\right.$, Dimensionless Blockage index $\left(I_{b^{\prime}}=\right.$

$534 \log \left(V_{D} /\left(H_{D}{ }^{*} A_{C}\right)\right)$, Basin index $\left(I_{a}=\log \left(H_{D}{ }^{2} / A_{C}\right)\right)$, Impoundment index $\left(I_{i}=\log \left(V_{D} / V_{L}\right)\right.$, and

535 Backstow index $\left(I_{s}=\log \left(H_{D}{ }^{3} / V_{L}\right)\right)$. All of these indices express some formulation of dam

536 size relative to the amount of water available to break the dam. Impoundment index and

537 Blockage index were introduced by Casagli and Ermini (1999), while the DBI used here

538 was introduced by Ermini and Casagli (2002). Basin index and Backstow index were

539 introduced by Korup (2004). As noted in section 2, all but one of the landslide dams in

540 our study area have been breached, so we cannot use presence of extant lakes as a

541 criterion for stability, and this approach has limitations in any case (section 1). We focus

542 instead on whether evidence exists for catastrophic dam failure at each site,

543 emphasizing the instability domain rather than the stability domain emphasized by

544 others (e.g., Korup, 2004). Absence of evidence for catastrophic failure is not evidence

545 of absence, and results must be interpreted with caution. Nonetheless, previous studies

546 have shown that field indications of outburst flooding are often well preserved in the

547 area (e.g., Beebee, 2003; O'Connor et al., 2003a), creating an opportunity to explore

548 whether morphometric indices could offer a quantitative, if simple, framework for

549 interpreting such evidence. Figure 8 depicts the range of values for the eastern Oregon

550 landslides relative to threshold values reported in the literature that discriminate "stable"

551 from dams that failed catastrophically or breached in an unspecified fashion in other

552 locations. For example, landslide dams considered stable (intact) in New Zealand have

553 Blockage index values of $>7$, while landslides characterized as intact using the

554 worldwide data set have Blockage index values of $>5$ (Korup, 2004; Fig. 8A). Based on 
555 New Zealand and worldwide data, breached landslide dams were found to have

556 Blockage index values of $<4$ and $<2$, respectively.

557 Consistent patterns emerge from the comparison (Figs. 8 A-C). First, the index values

558 partially separating intact from breached landslide dams in the New Zealand data set

559 (Korup, 2004) are higher than those for the dams of eastern Oregon, particularly for the

560 Basin index (Fig. 8C). By contrast, discriminating values of Blockage index and

561 Dimensionless Blockage index derived from worldwide data are consistent with

562 observations in eastern Oregon. The Wolf Creek and Lake Magone sites, which lack

563 evidence for catastrophic failure, fall into the stable domain; the Chukar Park site falls

564 into the stable or marginally stable domain; and most of the rest of the sites showing

565 evidence of catastrophic failure are within the unstable domain. In the field, the Chukar

566 Park landslide dam exhibits elements of persistence and of catastrophic failure. The

567 reach upstream of the dam site is a broad, sediment-floored valley characterized by

568 numerous meander cutoffs in which the river's course is highly sinuous. This gives way

569 at the dam site to a relatively straight channel full of rapids (Fig. 9). The morphology of

570 the reach upstream of the dam site suggests that the dam itself or a topographically

571 significant lag persisted sufficiently long, perhaps several centuries or more, for a

572 substantial quantity of sediment to accumulate upstream. However, boulder bars along

573 the downstream end of the landslide attest to outburst flooding from the zone we

574 consider the most recently active part of the landslide, indicating at least partial

575 cataclysmic breaching. This multipronged (and multifaceted) landslide character is

576 common to several other eastern Oregon landslides (e.g., West Springs Greeley, Warm

577 Springs Reservoir) and complicates dam stability analysis. 

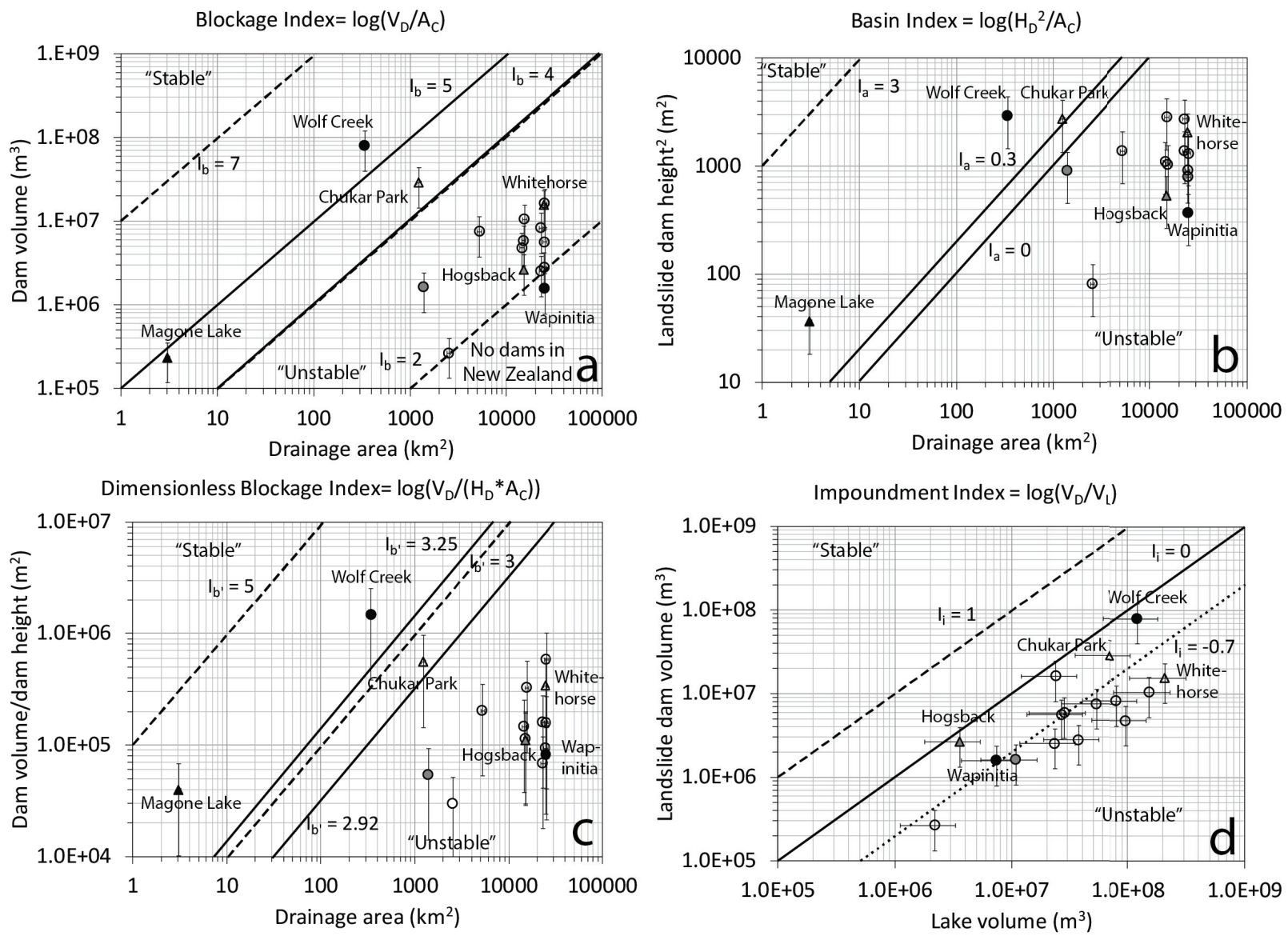

Backstow Index $=\log \left(\mathrm{H}_{\mathrm{D}}{ }^{3} / \mathrm{N}_{\mathrm{L}}\right)$

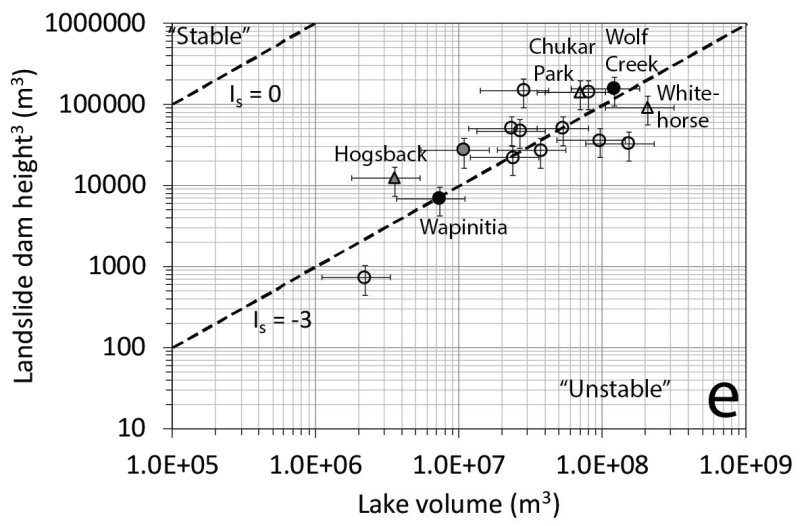

Fig. 8. Morphometric index values, computed from measured characteristics of landslide dams, impounded lakes, and upstream catchments. Size of error bars reflect estimated error in measured quantities (section 4.1), which were propagated through derived quantities (e.g., $H_{D} x$ $A_{C}$ ). Lines show threshold index values separating dams that were deemed stable vs. unstable in various localities (Ermini and Casagli, 2003; Korup, 2004). Meaning of stable and unstable designations are explained in section 1. Solid lines: Worldwide data (Ermini and Casagli, 2003; Korup, 2004). Dashed lines: New Zealand (Korup, 2004). Dotted line, fitted by eye (panel D 

circles are dam sites downstream of which we lack field observations. Solid black circles are dams exhibiting no evidence of outburst flooding and are labeled with site names, as are

590 triangles: dam sites associated with knickpoints.

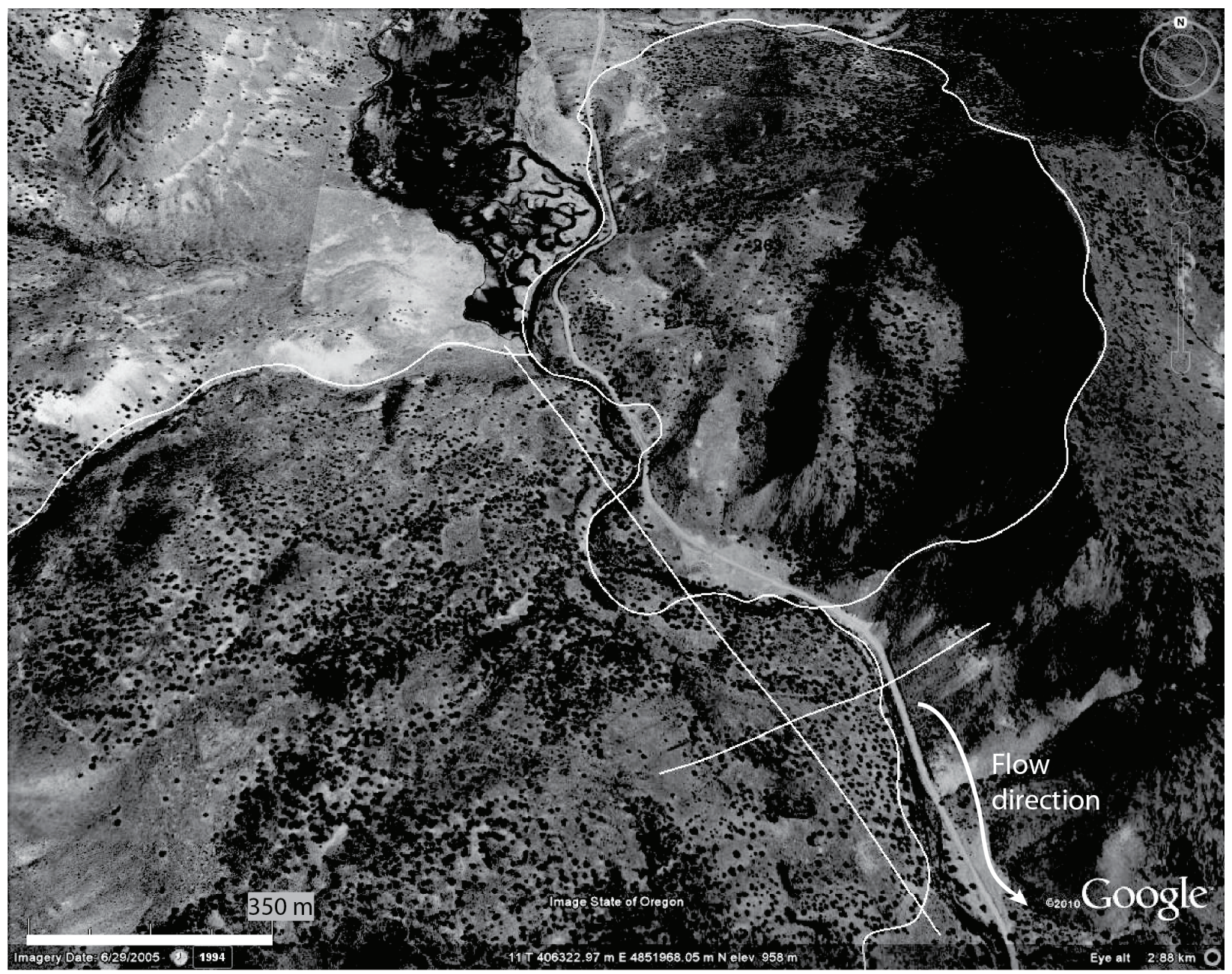

Fig. 9. Oblique Google Earth image of Chukar Park landslide dam site. North Fork Malheur the river on both sides. Based on field observations, the landslide dam crest is believed to be along the short, valley-perpendicular line, and the breach zone is spanned by the long, valleyparallel line. 
601 reaches (Fig. 7). However, these sites do not all occupy the same region on the 602 bivariate plots. The Whitehorse and Hogsback dams fall within the unstable domains of 603 the Blockage, Basin, and Dimensionless Blockage index plots, while Magone Lake and 604 Chukar Park do not. In the field, the Hogsback site lacks evidence of upstream 605 sediment accumulation. Terraces do occur upstream from the Whitehorse dam site, but 606 the sediment accumulation is not nearly as extensive as upstream from the Chukar Park 607 site.

Two sites, Warm Springs River and Hogsback, whose downstream reaches we 609 were unable to observe in the field, plot in unstable domains of the Basin index, 610 Blockage index, and Dimensionless Blockage index graphs (Figs. 8A-C). This result 611 constitutes a prediction that can be tested if we gain access to those sites. One site, 612 Wapinitia, shows no clear field evidence of catastrophic dam failure and also plots in the 613 unstable region of these graphs. At Wapinitia, another landslide complex impinges on 614 the channel immediately downstream of the dam site, possibly covering or obliterating 615 outburst flood deposits from breaching of the Wapinitia landslide. The downstream 616 landslide complex, which gives rise to Boxcar Rapids on the Deschutes River, is judged 617 by Beebee (2003) to be younger than Wapinitia, based on apparent freshness of slide 618 mass morphology, and auger data are consistent with this observation (section 3).

619 However, if we take the field evidence at face value, the Basin, Blockage, and

620 Dimensionless Blockage indices all mischaracterize the Wapinitia site as being 621 susceptible to catastrophic failure. The Impoundment index cleanly separates the landslide dams that do and do not 623 exhibit evidence for catastrophic failure (Fig. 8D). However, the discriminating value is - 
6240.7 , rather than 0 for worldwide data or 1 for New Zealand data. The Hogsback site is 625 predicted not to have failed catastrophically, according to this value.

626 The Backstow index is the poorest at discriminating eastern Oregon dam sites

627 with and without evidence of catastrophic dam failure (Fig. 8E). Index values for the

628 stable and unstable dams substantially overlap. The threshold value for stable dams in

629 New Zealand lies far above those from our sites, and the threshold for unstable dams

630 runs through the middle of the eastern Oregon observations (Fig. 8E).

631

632 6. Discussion

633 Overall, most of the ancient dam sites we analyzed in eastern Oregon appear to 634 have been unstable. Only three of the 17 sites with channel-blocking landslides lack 635 evidence for catastrophic outburst flooding. Figure 10 illustrates an example of such 636 field evidence. 

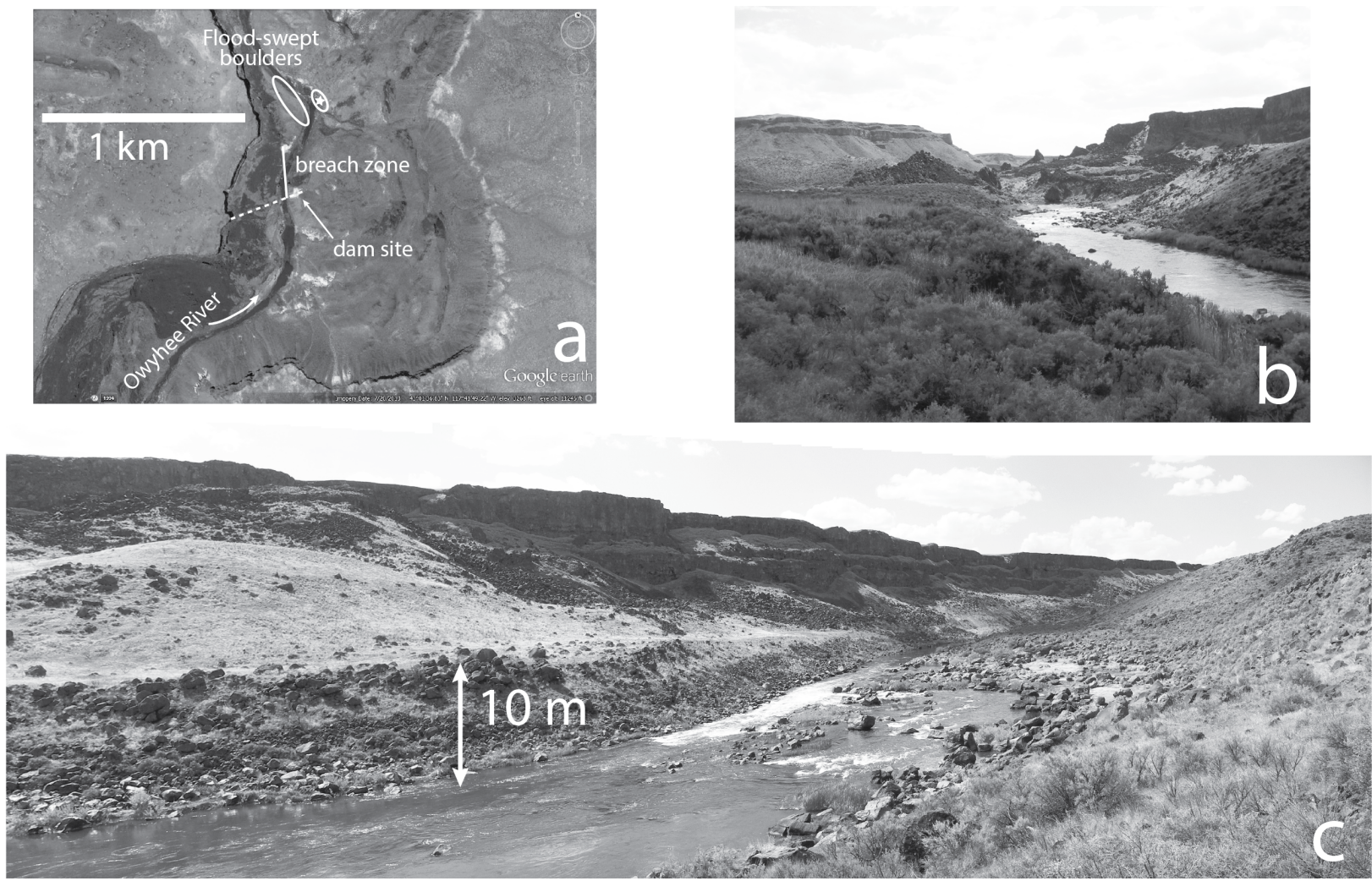

638 Fig. 10. Field evidence for outburst flooding, Artillery landslide reach. (A) Artillery landslide

639 complex, illustrating location of critical cross-section at dam site (dashed line; near location of

640 Fig. 3), breach zone (solid line), and terraces capped by flood-swept boulders (ellipses). Star

641 marks location from which photos in (B) and (C) were taken. Image from Google Earth. (B) View

642 upstream toward dam site. (C) Panoramic view across valley and downstream.

644 The percentage ( $82 \%$ ) of dams in eastern Oregon that failed catastrophically exceeds

645 the 45 to $70 \%$ (depending on materials involved) reported for worldwide data (Ermini

646 and Casagli, 2002) and the $37 \%$ of unstable dams in New Zealand (Korup, 2004). Field

647 evidence for widespread catastrophic failure of eastern Oregon landslide dams is

648 consistent with the implications of landslide dam stability indices, given the

649 morphometric character of the region's landslide dams and their impoundments. The

650 ratio of dam size to impoundment size is smaller in eastern Oregon than for other

651 settings (Fig. 5), and broadly speaking, smaller ratios promote instability as predicted by

652 the indices. 
A complication of our analysis is that the landslide complexes that generate dams in eastern Oregon are in some cases many square kilometers in extent, yet the dams themselves are commonly formed by only a small finger of landslide material. The 656 most striking example of this is the Warm Springs Reservoir site, which has the largest 657 landslide complex area $\left(39.6 \mathrm{~km}^{2}\right)$ and one of the smallest landslide dam volumes $658\left(264,600 \mathrm{~m}^{3}\right)$ in our data set. The dynamics of these landslide complexes are not well 659 understood, but some of them appear to be progressive (Othus, 2008; Safran et al., 660 2011; Markley, 2013). While some of the region's landslide complexes have clearly 661 persisted for many tens of thousands of years (Safran et al., 2011), in most cases, the 662 whole slide mass is not active at any one time (Othus, 2008; Markley, 2013). Field 663 evidence of channel damming and of dam breaching likely relates only to the most 664 recent blockage or blockages. The length scale of a dam might be set by the dominant 665 topographic wavelengths in the landslide mass, which in turn may depend on landslide 666 type and material. Along portions of the Owyhee River, for example, failure slices in 667 multiple rotational complexes are typically spaced several tens to $\sim 100 \mathrm{~m}$ apart (Safran 668 et al., 2011; Markley, 2013). The impingement of these blocks on the channel at an 669 angle helps to set the scale of the along-channel dam dimension, typically on the order 670 of several hundreds of meters. We are currently working to better quantify and identify 671 the controls on intraslide topography in eastern Oregon (Markley, 2013).

672 In contrast to relatively small landslide dam volumes, the lake volumes and/or 673 upstream catchment areas of dammed channels are relatively large in eastern Oregon.

674 Large impoundments result from the low regional gradients that characterize this 675 plateau environment. Low channel gradients (predominantly 0.002-0.005, except near 
676 Magone Lake: $\sim 0.04$ ) result in long lakes on the order of $10 \mathrm{~km}$ (Fig. 5). Lake volumes

677 are also enhanced by the large landslide complexes themselves, which widen valleys

678 by locally reducing valley wall gradients to $8-14^{\circ}$ (Safran et al., 2011).

679 The large drainage areas of the channels at our dam sites are a function of the 680 dominant regional controls on landslide occurrence. In a landslide distribution analysis, 681 Safran et al. (2011) showed that eastern Oregon landslides are preferentially localized 682 where coherent, typically volcanic, rocks overlie weak, typically fluviolacustrine or 683 volcaniclastic units, along escarpments and canyon walls. The distribution of the key 684 contacts that promote landsliding is established by the volcanic and tectonic history of 685 the region and is largely independent of geomorphic controls; these key contacts can 686 outcrop anywhere along a channel network. At the same time, the relief to drive 687 landsliding is largely confined to tectonic or volcanic escarpments or to the walls of 688 canyons. Although only modest local relief $(\sim 100 \mathrm{~m})$ is required to drive mass 689 movement where key contacts are exposed (Safran et al., 2011), in this relatively low 690 relief environment characterized by accumulation of volcaniclastic and volcanic deposits 691 since at least Miocene times, such exposures are most common along major rivers. 692 Thus, the conditions for landslide dam formation are commonly met on channels with 693 large drainage areas. This distinguishes the eastern Oregon landscape from montane 694 settings in which topographic gradients dominate large landslide distributions (Korup et 695 al., 2007). In such mountainous settings, the steepest and most landslide-prone slopes 696 may be in headwater areas with relatively low drainage areas. Because in eastern 697 Oregon landslide dam volume does not increase systematically with drainage area of 
698 the adjacent channel (Fig. 6), conditions for catastrophic dam failure can likewise occur 699 throughout these large basins.

Landslides on high-order channels potentially disrupt fluvial architecture (Korup 701 and Crozier, 2002) and longitudinal profile evolution (Ouimet et al., 2007; Safran et al., 702 2008). However, significant inhibition of valley incision over timescales of $10^{6}$ years

703 requires repeated and relatively persistent (e.g., $10^{3}-10^{4}$ years) landslide dams, dam 704 remnants, or upstream sediment accumulations that create channel "plugs" (Safran et 705 al., 2008). There is no timescale associated with morphometry-based dam stability 706 assessments. Based on historical data, Costa and Shuster $(1988,1991)$ reported that $70785 \%$ of landslide dams that fail do so within a year of formation, but many landslide 708 dams do not fail. Moreover, Hewitt (1998), Ermini and Casagli (2002), and Hermanns et 709 al. $(2006,2011 a)$ noted that landslide dam stability for hundreds or even thousands of 710 years does not preclude the possibility of ultimate catastrophic failure.

711 Complex landslide and flood histories have been documented in individual

712 instances around the world (e.g., Hewitt, 1998; Hermanns et al., 2004, 2006, 2009,

713 2011a), but the relative importance of various controls on dam longevity remain

714 uncertain. Some emphasize the importance of lithologic and geotechnical properties of

715 dams, such as grain size or degree of fragmentation, on dam persistence (Ermini and

716 Casagli, 2002; Casagli et al., 2003; Davies and McSaveney, 2006; Dunning and

717 Armitage, 2011). Others highlight time-dependent controls on dam integrity, such as the 718 interplay between three-dimensional dam morphology and the surrounding bedrock

719 (Dunning et al., 2005; Hermanns et al., 2009, 2011b); climatic variability (Hermanns et 
al., 2004; 2011a); and individual hydrologic and mass-wasting events affecting dams or

721 their associated impoundments (Hermanns et al., 2004, 2011a).

Although none of the eastern Oregon landslide dams have sufficient absolute

723 age information to determine their persistence, about half of the dam sites we studied

724 possibly have upstream sediment accumulations (Table 1). This implies at least some

725 period of landslide dam stability prior to breaching. In most cases, however, breaching

726 was at least partly catastrophic, leaving downstream evidence of flooding. Only

727 impoundments not completely filled with sediment could produce such flooding.

$728 \quad$ Even short-lived landslide dams or incomplete valley occlusions can have local

729 impacts on longitudinal profiles. Four of the eastern Oregon dam sites appear spatially

730 associated with some sort of convexity in the longitudinal profile of the channel

731 upstream of the dam site (Fig. 7), although only the knickpoint at Whitehorse is depicted

732 in detail with high-resolution topographic data. As noted in section 3, the Magone Lake,

733 Chukar Park, and Hogsback dam sites are known (Magone Lake) or suspected to be of

734 Holocene age, possibly post-dating the Mazama eruption, which may help explain the

735 relative prominence of the associated knickpoints, although the Whitehorse dam is likely

736 older (section 3). Perturbations associated with landslide dams do not appear to govern

737 the overall form of the longitudinal profile as seen, for example, by Ouimet et al. (2007)

738 in landslide-affected reaches in eastern China. Modeling of the morphologic

739 consequences of landslide dam-related incision inhibition suggests that those more

740 significant impacts on the longitudinal profile, which include long-wavelength (tens of

741 kilometers) convexities with amplitudes of hundreds of meters, require spatial clustering

742 of landslides, long-term persistence of landslide dams relative to the rate of base-level 
743 lowering, and few floods capable of mobilizing large landslide lag material or incising

744 into bedrock (Safran et al., 2008). In some cases, dam-failure floods are the only flows

745 capable of moving large in-channel landslide debris (Beebee, 2003) that localizes

746 knickpoints. Reactivation of individual landslide complexes is commonplace, and in

747 eastern Oregon multiple dams may be generated over time at a single site or along a

748 channel reach (e.g., Othus, 2008; Safran et al., 2011). However, despite landslide-

749 related features that dominate the geomorphic character of some channel reaches in

750 the region for thousands of years (e.g., O'Connor et al., 2003a), there is little evidence

751 thus far that the ancient landslide dams in eastern Oregon control the longer-term,

752 million-year-timescale evolution of longitudinal profiles by forming lasting plugs.

753 Landslide dam stability assessments based on morphometric indices offer a blunt

754 but simple tool for characterizing the relative propensity for dams in a given environment

755 to fail. They are subject to error because they neglect a variety of important controls,

756 including those described above. Nonetheless, this study indicates that the functional

757 form, and in some cases even the threshold values, of several morphometric indices are

758 applicable to landslide dams in this semiarid, low-relief environment. The threshold

759 values of Blockage and Dimensionless Blockage indices calibrated to worldwide data

760 appear most applicable to the eastern Oregon data, perhaps because of the diverse

761 range of environments these data sets include. The threshold values of the Blockage

762 and Impoundment indices calibrated to the Apennines are higher than the thresholds

763 applicable to the eastern Oregon data.

764 The threshold values derived from the New Zealand data are the highest of all 765 and do not appear to have predictive value for the landslide dams of eastern Oregon. 
766 For a given metric of water available for dam breaching (e.g., upstream catchment area

767 or lake volume), dam volumes must be several orders of magnitude greater to be stable

768 in New Zealand than in eastern Oregon. Korup (2004) speculated that the stability of

769 dams in New Zealand may be limited by rapid rates of surface erosion related to

770 earthquakes and the abundance of high-intensity rainstorms. Geotechnical properties of

771 landslide dams may also differ between the two regions, such as material size, sorting,

772 and compaction, which themselves might relate to landslide type (e.g., rockfall vs.

773 earthflow) and lithologic controls. Further work is required to explore these linkages

774 systematically.

775

7767 Conclusion

777 The stability of landslide dams can mediate the effects of hillslope form and

778 processes on fluvial incision and therefore on regional landscape evolution. Eastern

779 Oregon is a relatively dry, low-relief, primarily extensional, continental interior

780 landscape. This tectonic setting promotes stratigraphic sequences, in particular lava

781 flows capping fluviolacustrine and volcaniclastic sediments, prone to landsliding along

782 river corridors of diverse drainage areas. The blocky or modular character of many of

783 the region's landslides produces dams that are small relative to the area of entire

784 landslide complexes. Low regional gradients lead to large water impoundments.

785 Previously developed bivariate indices of landslide stability suggest that a small ratio of

786 dam volume to water available for dam breaching, as found in eastern Oregon,

787 promotes catastrophic dam failure. Such failures are indicated by flood deposits

788 downstream of most of the dam sites studied. While the landslide dams of eastern 
789 Oregon may temporarily serve as channel plugs, their general instability implies that 790 they are primarily flood-makers. Future research on the effects of repeated outburst 791 flooding on long-term incision rates is needed.

792

\section{Acknowledgments}

This work was funded by the Geological Society of America's Gladys Cole Award; National Science Foundation grant EAR-617347; and the John S. Rogers Summer Internship Program at Lewis \& Clark College. Owyhee River lidar topographic 797 data were obtained through the National Center for Airborne Laser Mapping (NCALM); 798 acquisition was partially funded by an NCALM seed grant. Funding sources had no role 799 in study design; collection, analysis, and interpretation of data; writing of this 800 manuscript; or the decision to submit this work for publication. Dylan Peden and Chris 801 Scheffler provided field assistance. JoJo Mangano and Miranda Wood facilitated stream 802 profile extraction from lidar and USGS topographic quads. The Bureau of Land 803 Management and local landowners granted access and logistical assistance. We thank 804 Oliver Korup and Richard Marston for the time and effort they devoted to helping us 805 improve this manuscript for publication. Any use of trade, firm, or product names is for 806 descriptive purposes only and does not imply endorsement by the U.S. Government. 807 


\section{References}

Beebee, R.A., 2003. Snowmelt hydrology, paleohydrology, and landslide dams in the Deschutes River basin, Oregon. Ph.D. Dissertation, University of Oregon, Eugene.

Beranek, L.P., Link, P.K., Fanning, C.M., 2006. Miocene to Holocene landscape evolution of the western Snake River Plain region, Idaho: Using the SHRIMP detrital zircon provenance record to track eastward migration of the Yellowstone hotspot. Geological Society of America Bulletin 118, 10271050, doi: 10.1130/B25896.1.

Burchsted, D., Daniels, M., Wohl, E.E., 2014. Introduction to the special issue on discontinuity of fluvial systems. Geomorphology 205, 1-4, doi: 10.1016/j.geomorph.2013.04.004.

Camp, V.E., Ross, M.E., 2004. Mantle dynamics and genesis of mafic magmatism in the intermontane Pacific Northwest. Journal of Geophysical Research 109, B08204, doi: 10.1029/2003JB002838.

Carter, D.T., Ely, L.L., O'Connor, J.E., Fenton, C.R., 2006. Late Pleistocene outburst flooding from pluvial Lake Alvord into the Owyhee River, Oregon. Geomorphology 75, 346-367.

Casagli, N., Ermini, L., 1999. Geomorphic analysis of landslide dams in the Northern Apennines. Transactions-Japanese Geomorphological Union 20(3), 219-249.

Casagli, N., Ermini, L., Rosati, G., 2003. Determining grain size distribution of the materials composing landslide dams in the Northern Apennines: sampling and processing methods. Engineering Geology 69, 83-97.

Christiansen, R.L., Yeats, R.S., 1992. Post-Laramide geology of the U. S. Cordilleran region. In: Burchfiel, B.C., Lipman, P.W., Zoback, M.L., (Eds.), The Cordilleran Orogen; Conterminous U.S. Decade of North American Geology. Geological Society of America, Denver, CO, v. G-3, pp. 261-406.

Costa, J.E., Schuster, R.L., 1988. The formation and failure of natural dams. Geological Society of America Bulletin 100, 1054-1068.

Costa, J.E., Schuster, R.L., 1991. Documented historical landslide dams from around the world. U. S. Geological Survey Open-File Report 91-239.

Cummings, M.L., 1991. Geology of the Deer Butte Formation, Malheur County, Oregon; faulting, sedimentation and volcanism in a post-caldera setting. Sedimentary Geology 74, 345-362.

Cummings, M.L., Evans, J.G., Ferns, M.L., Lees, K.R., 2000. Stratigraphic and structural evolution of the middle Miocene synvolcanic Oregon-Idaho graben. Geological Society of America Bulletin 112, 668-682.

Davies, T.R., McSaveney, M.J., 2006. Dynamic fragmentation in landslides: Application to natural dam stability. Italian Journal of Engineering Geology and Environment, Special Issue I, 123-126, doi: 10.4408/IJEGE:200601.S-16. 
Dunning, S.A., Armitage, P.J., 2011. The grain-size distribution of rockavalanche deposits: Implications for natural dam stability. In: Evans, S.G., Hermanns, R.L., Strom, A., Scarascia-Mugnozza, G. (Eds.), Natural and Artificial Rockslide Dams, Lecture Notes in Earth Sciences (volume 133). Springer Berlin Heidelberg, pp. 479-498, doi: 10.1007/978-3-642-047640_19.

Dunning, S., Petley, D., Rosser, N., Strom, A., 2005. The morphology and sedimentology of valley confined rock-avalanche deposits and their effect on potential dam hazard. In: Hungr, O., Fell, R., Couture, R., Eberhardt, E. (Eds.), Landslide Risk Management. Taylor and Francis Group, London, pp. 691-701.

Ely, L. E., Brossy, C. C., House, P. K., Safran, E. B., O'Connor, J. E., Champion, D. E., Fenton, C. R., Bondre, N. R., Orem, C. A., Grant, G. E., Henry, C. D., Turin, B. D., 2012. Owyhee River intracanyon lava flows: Does the river give a dam? Geological Society of America Bulletin 124, 1667-1687, doi: 10.1130/B30574.1.

Ermini, L., Casagli, N., 2002. Criteria for a preliminary assessment of landslide dam evolution. In: Rybar, J., Sternbeck, J., Wagner, P., (Eds.), Landslides. Proceedings 1st European Conference on Landslides 24-26 June 2002, Prague, Balkema, pp. 157-162.

Ermini, L., Casagli, N., 2003. Prediction of the behavior of landslide dams using a geomorphical dimensionless index. Earth Surface Processes and Landforms 28, 31-47.

Hermanns, R.L., Niedermann, S., Ivy-Ochs, S., Kubik, P.W., 2004. Rock avalanching into a landslide-dammed lake causing multiple dam failure in Las Conchas valley (NW Argentina) - evidence from surface exposure dating and stratigraphic analyses. Landslides 1, 113-122, doi: 10.1007/s10346-004-0013-5.

Hermanns, R.L., Folguera, A., Gonzales Diaz, F.E., Fauque, L., 2006. Landslide dams in the Central Andes of Argentina - showing the need of revising the established landslide dam classification. Italian Journal of Engineering Geology and Environment, Special Issue I, 55-60, doi: 10.4408/IJEGE:2006-01.S-06.

Hermanns, R.L., Blikra, L.H., Longva, O., 2009. Relation between rockslide dam and valley morphology and its impact on rockslide dam longevity and control on potential breach development based on examples from Norway and the Andes. In: Bauer, E., Semprich, S., Zenz, G. (Eds.), Long Term Behavior of Dams: Proceedings of the 2nd International Conference. Verlag der Technischen Universität Graz, Graz, pp. 789-794.

Hermanns, R.L., Folguera, A., Penna, I., Fauque, L., Niedermann, S., 2011a. Landslide dams in the Central Andes of Argentina (Northern Patagonia and the Argentine Northwest). In: Evans, S.G., Hermanns, R.L., Strom, A., Scarascia-Mugnozza, G. (Eds.), Natural and Artificial Rockslide Dams, Lecture Notes in Earth Sciences (volume 133). Springer Berlin Heidelberg, pp. 147-176. 
Hermanns, R.L., Hewitt, K., Strom, A., Evans, S.G., Dunning, S.A., ScarasciaMugnozza, G., 2011b. The classification of rockslide dams. In: Evans, S.G., Hermanns, R.L., Strom, A., Scarascia-Mugnozza, G. (Eds.), Natural and Artificial Rockslide Dams, Lecture Notes in Earth Sciences (volume 133). Springer Berlin Heidelberg, pp. 581-593.

Hewitt, K., 1998. Catastrophic landslides and their effects on the Upper Indus streams, Karakoram Himalaya, northern Pakistan. Geomorphology 26, 4780.

Hewitt, K., 2006. Disturbance regime landscapes: mountain drainage systems interrupted by large rockslides. Progress in Physical Geography 30, 365393, doi: 10.1191/0309133306pp486ra.

Hewitt, K., Clague, J.J., Orwin, J.F., 2008. Legacies of catastrophic rock slope failures in mountain landscapes. Earth Science Reviews 87, 1-38.

Hewitt, K., Gosse, J., Clague, J.J., 2011. Rock avalanches and the pace of late Quaternary development of river valleys in the Karakorum Himalaya. Geological Society of America Bulletin 123, 1836-1850.

Ibarra, D.E., Egger, A.E., Weaver, K.L., Harris, C.R., Maher, K., 2014. Rise and fall of late Pleistocene pluvial lakes in response to reduced evaporation and precipitation: Evidence from Lake Surprise, California. Geological Society of America Bulletin 126, 1387-1415, doi: 10.1130/B31014.1.

Korup, O., 2002. Recent research on landslide dams; a literature review with special attention to New Zealand. Progress in Physical Geography 26, 206-235.

Korup, O., 2004. Geomorphic characteristics of New Zealand landslide dams. Engineering Geology 73, 13-35.

Korup, O., 2005. Large landslides and their effect on sediment flux in South Westland, New Zealand. Earth Surface Processes and Landforms 30, 305323, doi: 10.1002/esp.1143.

Korup, O., 2006. Rock-slope failure and the river long profile. Geology 34, 4548.

Korup, O., 2011. Rockslide and rock avalanche dams in the Southern Alps, New Zealand. In: Evans, S.G., Hermanns, R.L., Strom, A., ScarasciaMugnozza, G. (Eds.), Natural and Artificial Rockslide Dams, Lecture Notes in Earth Sciences (volume 133). Springer Berlin Heidelberg, pp. 123-145.

Korup, O., Crozier, M., 2002. Landslide types and geomorphic impact on river channels, Southern Alps, New Zealand. In: Rybar, J., Sternbeck, J., Wagner, P., (Eds.), Landslides. Proceedings 1st European Conference on Landslides 24-26 June 2002, Prague, Balkema, pp. 233-238.

Korup, O., Strom, A.L., Weidinger, J.T., 2006. Fluvial response to large rockslope failures: Examples from the Himalayas, the Tien Shan, and the Southern Alps in New Zealand. Geomorphology 78, 3-21.

Korup, O., Clague, J.J., Hermanns, R.L., Hewitt, K., Strom, A.L., Weidinger, J.T., 2007. Giant landslides, topography, and erosion. Earth and Planetary Science Letters 261, 578-589. 
982

983

984

Korup, O., Densmore, A.L., Schlunegger, F., 2010. The role of landslides in mountain range evolution. Geomorphology 120 , 77-90, doi: 10.1016/j.geomorph.2009.09.017.

Markley, C., 2013. Characterization of mass wasting through the spectral analysis of LiDAR imagery: Owyhee River, southeastern Oregon. M.S. Thesis, Central Washington University, Ellensburg.

Mosgrove, J.L., 1980. The Malheur National Forest: An Ethnographic History. USDA Forest Service, Pacific Northwest Region, Portland, U.S.A.

O'Connor, J.E., Beebee, R.A., 2009. Floods from natural rock-material dams. In Burr, D., Carling, P., Baker, V. (Eds.), Megafloods on Earth and Mars. Cambridge University Press, Cambridge, U.K., pp. 128-171.

O'Connor, J.E., Grant, G.E., (Eds.), 2003. A Peculiar River, The Geology and Geomorphology of the Deschutes River, Oregon. American Geophysical Union Water Science and Application Series No. 7, Washington, DC, 219 pp.

O’Connor, J.E., Curran, J.H., Beebee, R.A., Grant, G.E., Sarna-Wojcicki, A., 2003a. Quaternary geology and geomorphology of the lower Deschutes River canyon, Oregon. In: O'Connor, J.E., and Grant, G.E., (Eds.), A Peculiar River-Geology, Geomorphology, and Hydrology of the Deschutes River, Oregon. American Geophysical Union Water Science and Application Series No. 7, Washington, DC, pp. 73-94.

O'Connor, J.E., Grant, G.E., Haluska, T.L., 2003b. Overview of geology, hydrology, geomorphology, and sediment budget of the Deschutes River basin, Oregon. In: O'Connor, J.E., Grant, G.E., (Eds.), A Peculiar RiverGeology, Geomorphology, and Hydrology of the Deschutes River, Oregon. American Geophysical Union Water Science and Application Series No. 7, Washington, DC, pp. 7-29.O'Connor, J.E., Clague, J.J., Walder, J.S., Manville, V., Beebee, R.A., 2013. Outburst Floods. In: Shroder, J. (Editor in Chief), Wohl, E.E., (Ed.), Treatise on Geomorphology, v. 9 (Fluvial Geomorphology). Academic Press, San Diego, U.S.A., pp. 475-510.

Oster, J.L., Ibarra, D.E, Winnick, M.J., Maher, K., 2015. Steering of westerly storms over western North America at the Last Glacial Maximum. Nature Geoscience 8, 201-205, doi: 10.1038/NGEO2365.

Othus, S.M., 2008. Comparison of Landslides and Their Related Outburst Flood Deposits, Owyhee River, Southeastern Oregon: M.S. Thesis, Central Washington University, Ellensburg.

Ouimet, W.B., Whipple, K.X., Royden, L.H., Ziming Sun, Ziliang Chen, 2007. The influence of large landslides on river incision in a transient landscape: Eastern margin of the Tibetan Plateau (Sichuan, China). Geological Society of America Bulletin 119, 1462-1476.

Philip, H., Ritz, J-F, 1999. Gigantic paleolandslide associated with active faulting along the Bogd fault (Gobi-Altay, Mongolia). Geology 27, 211-214.

Reneau, S.L., Dethier, D.P., 1996. Late Pleistocene landslide-dammed lakes along the Rio Grande, White Rock Canyon, New Mexico. Geological Society of America Bulletin 108, 1492-1507. 
Repenning, C.A., Weasma, T.R., Scott, G.R., 1995. The early Pleistocene (lastest Blancan-earliest Irvingtonian) Froman Ferry fauna and history of the Glenns Ferry Formation, southwestern Idaho. U.S. Geological Survey Bulletin 2105.

Safran, E.B., Peden, J.D., Harrity, K., Anderson, S.W., O'Connor, J.E., Wallick, R., House, P.K., Ely, L., 2008. Impacts of landslide dams on river profile evolution. Eos Transactions of the American Geophysical Union 89(53), Fall Meeting Supplement, Abstract H54D-03.

Safran, E.B., Anderson, S.W., Mills-Novoa, M., House, P.K., Ely, L., 2011. Controls on large landslide distribution and implications for the geomorphic evolution of the southern interior Columbia River basin. Geological Society of America Bulletin 123, 1851-1862.

Schuster, R.L., 2006. Impact of landslide dams on mountain valley morphology. In: Evans, S.G., Hermanns, R.L., Strom, A., Scarascia-Mugnozza, G. (Eds.), Natural and Artificial Rockslide Dams, Lecture Notes in Earth Sciences (volume 133). Springer Berlin Heidelberg, pp. 591-616.

Smith, G.A., 1986. Simtustus Formation: Paleogeographic and stratigraphic significance of a newly defined Miocene unit in the Deschutes basin, central Oregon. Oregon Geology 48, 63-72.

van Gorp, W., Temme, J.A.M., Baartman, J.E.M., Schoorl, J.M., 2014. Landscape evolution modeling of naturally dammed rivers. Earth Surface Processes and Landforms 39, 1587-1600, doi: 10.1002/esp.3547.

Van Tassell, J., Ferns, M., McConnell, V., Smith, G. R., 2001. The mid-Pliocene Imbler fish fossils, Grande Ronde Valley, Union County, Oregon, and the connection between Lake Idaho and the Columbia River. Oregon Geology 63, 77-84 and 89-96.

Walsh, L.S., Martin, A.J., Ojha, T.P., Fedenczuk, T., 2012. Correlations of fluvial knickzones with landslide dams, lithologic contacts, and faults in the southwestern Annapurna Range, central Nepalese Himalaya. Journal of Geophysical Research 117, F01012, doi: 10.1029/2011JF001984.

Whipple, K.X., Tucker, G.E., 1999. Dynamics of the stream-power river incision model: Implications for height limits of mountain ranges, landscape response time-scales, and research needs. Journal Geophysical Research 104(B8), 17,661-17,674. 
Table 1

Eastern Oregon landslide dam sites analyzed in this study

\begin{tabular}{|c|c|c|c|c|c|c|c|c|c|c|c|c|}
\hline Site name & $\begin{array}{l}\text { Major } \\
\text { river } \\
\text { basin }\end{array}$ & $\begin{array}{l}\text { Long. } \\
\text { (decimal } \\
\text { degrees) }\end{array}$ & $\begin{array}{l}\text { Lat. } \\
\text { (decimal } \\
\text { degrees) }\end{array}$ & $\begin{array}{l}\text { Landslide } \\
\text { complex } \\
\text { area }\left(\mathrm{km}^{2}\right)\end{array}$ & $\begin{array}{l}\text { Landslide } \\
\text { type }\end{array}$ & $\begin{array}{l}\text { Evidence for } \\
\text { blockage and } \\
\text { persistence/ } \\
\text { failure }\end{array}$ & $\begin{array}{l}\text { Drainage } \\
\text { area } \\
\text { upstream } \\
\text { of } \\
\text { blockage } \\
\left(\mathrm{km}^{2}\right) \\
\end{array}$ & $\begin{array}{l}\text { Lanc } \\
\text { heig } \\
\text { wid }\end{array}$ & $\begin{array}{l}\text { Islide } \\
\text { ht/len } \\
\text { h (m) }\end{array}$ & am & $\begin{array}{l}\text { Lake } \\
\text { vol. } \\
\left(\mathrm{m}^{3}\right)\end{array}$ & $\begin{array}{l}\text { Lake } \\
\text { Length } \\
\text { (m) }\end{array}$ \\
\hline Whitehorse & Deschutes & 121.0782 & 44.9393 & 7.1 & $\begin{array}{l}\text { Complex } \\
\text { rotational } \\
\text { failure }\end{array}$ & $\begin{array}{l}\text { Terraces } \\
\text { upstream, } \\
\text { boulder bars } \\
\text { downstream }\end{array}$ & 24645 & 45 & 359 & 950 & $\begin{array}{l}2.09 \\
\times 10^{8}\end{array}$ & $\begin{array}{l}2.13 x \\
10^{4}\end{array}$ \\
\hline Dant & Deschutes & 121.1154 & 45.0440 & 0.4 & $\begin{array}{l}\text { Debris } \\
\text { flow }\end{array}$ & $\begin{array}{l}\text { Lake } \\
\text { sediments } \\
\text { upstream, } \\
\text { boulder lag } \\
\text { downstream }\end{array}$ & 24827 & 30 & 166 & 560 & $\begin{array}{l}3.74 \\
\times 10^{7}\end{array}$ & $\begin{array}{l}1.31 x \\
10^{4}\end{array}$ \\
\hline Wapinitia & Deschutes & 121.1240 & 45.1473 & 0.7 & $\begin{array}{l}\text { Complex } \\
\text { rotational } \\
\text { failure } \\
\end{array}$ & & 25164 & 19 & 206 & 400 & $\begin{array}{l}7.39 \\
\times 10^{6}\end{array}$ & $\begin{array}{l}7.99 x \\
10^{3}\end{array}$ \\
\hline $\begin{array}{l}\text { Warm } \\
\text { Springs } \\
\text { River }\end{array}$ & Deschutes & 121.0936 & 44.8651 & 1.1 & $\begin{array}{l}\text { Debris } \\
\text { flow }\end{array}$ & & 1401 & 30 & 195 & 275 & $\begin{array}{l}1.09 \\
\times 10^{7}\end{array}$ & $\begin{array}{l}6.50 x \\
10^{3}\end{array}$ \\
\hline $\begin{array}{l}\text { Magone } \\
\text { Lake }\end{array}$ & John Day & 118.9144 & 44.5460 & 0.4 & $\begin{array}{l}\text { Rock } \\
\text { avalanche } \\
? \\
\end{array}$ & Extant lake & 3 & 6 & 100 & 390 & $N D^{a}$ & $\begin{array}{l}8.75 x \\
10^{2}\end{array}$ \\
\hline Sheep Rock & John Day & 119.6382 & 44.6210 & 9.7 & $\begin{array}{l}\text { Complex } \\
\text { rotational } \\
\text { failure }\end{array}$ & $\begin{array}{l}\text { Suspected } \\
\text { lake } \\
\text { sediments } \\
\text { upstream, } \\
\text { flood torrent } \\
\text { terrace } \\
\text { downstream } \\
\end{array}$ & 5292 & 37 & 367 & 550 & $\begin{array}{l}5.32 \\
\times 10^{7}\end{array}$ & $\begin{array}{l}1.08 x \\
10^{4}\end{array}$ \\
\hline $\begin{array}{l}\text { Burnt } \\
\text { Ranch }\end{array}$ & John Day & 120.3533 & 44.7436 & 3.2 & Earth flow & $\begin{array}{l}\text { Terraces } \\
\text { upstream, } \\
\text { boulder bars } \\
\text { and elevated } \\
\text { gravel }\end{array}$ & 14567 & 33 & 289 & 500 & $\begin{array}{l}9.62 \\
\times 10^{7}\end{array}$ & $\begin{array}{l}2.15 x \\
10^{4}\end{array}$ \\
\hline
\end{tabular}




\begin{tabular}{|c|c|c|c|c|c|c|c|c|c|c|c|c|}
\hline & & & & & & $\begin{array}{l}\text { deposits } \\
\text { downstream }\end{array}$ & & & & & & \\
\hline Clarno & John Day & 120.4770 & 44.9668 & 33.6 & $\begin{array}{l}\text { Complex } \\
\text { rotational } \\
\text { failure }\end{array}$ & $\begin{array}{l}\text { Flood swept } \\
\text { boulders on } \\
\text { downstream } \\
\text { end of dam }\end{array}$ & 15533 & 32 & 379 & 860 & $\begin{array}{l}1.53 \\
\times 10^{8}\end{array}$ & $\begin{array}{l}2.52 x \\
10^{4}\end{array}$ \\
\hline Wolf Creek & Malheur & 118.6523 & 43.9491 & 11.3 & $\begin{array}{l}\text { Earth } \\
\text { spread }\end{array}$ & $\begin{array}{l}\text { Extensive } \\
\text { gravel } \\
\text { accumulation } \\
\text { upstream }\end{array}$ & 341 & 54 & 447 & $\begin{array}{l}328 \\
0\end{array}$ & $\begin{array}{l}1.21 \\
\times 10^{8}\end{array}$ & $\begin{array}{l}6.80 x \\
10^{3}\end{array}$ \\
\hline $\begin{array}{l}\text { Warm } \\
\text { Springs } \\
\text { Reservoir }\end{array}$ & Malheur & 118.2752 & 43.6963 & 39.6 & $\begin{array}{l}\text { Earth } \\
\text { spread }\end{array}$ & $\begin{array}{l}\text { Boulder bars } \\
\text { downstream }\end{array}$ & 2530 & 9 & 84 & 350 & $\begin{array}{l}2.21 \\
\times 10^{6}\end{array}$ & $\begin{array}{l}4.41 x \\
10^{3}\end{array}$ \\
\hline $\begin{array}{l}\text { Chukar } \\
\text { Park }\end{array}$ & Malheur & 118.1584 & 43.8109 & 2.4 & $\begin{array}{l}\text { Complex } \\
\text { rotational } \\
\text { failure }\end{array}$ & $\begin{array}{l}\text { Sediment } \\
\text { accumulation } \\
\text { and change } \\
\text { in river } \\
\text { morphology } \\
\text { upstream, } \\
\text { boulder bars } \\
\text { downstream }\end{array}$ & 1235 & 52 & 368 & $\begin{array}{l}150 \\
0\end{array}$ & $\begin{array}{l}7.02 \\
\times 10^{7}\end{array}$ & $\begin{array}{l}1.02 x \\
10^{4}\end{array}$ \\
\hline Hogsback & Owyhee & 117.2550 & 42.6546 & 1.2 & $\begin{array}{l}\text { Complex } \\
\text { rotational } \\
\text { failure }\end{array}$ & & 15166 & 23 & 172 & 660 & $\begin{array}{l}3.58 \\
\times 10^{6}\end{array}$ & $\begin{array}{l}6.16 x \\
10^{3}\end{array}$ \\
\hline $\begin{array}{l}\text { Deary } \\
\text { Pasture }\end{array}$ & Owyhee & 117.2684 & 42.6670 & 1.2 & $\begin{array}{l}\text { Complex } \\
\text { rotational } \\
\text { failure }\end{array}$ & $\begin{array}{l}\text { Flood swept } \\
\text { boulders } \\
\text { downstream } \\
\text { of blockage }\end{array}$ & 15169 & 53 & 210 & 525 & $\begin{array}{l}2.83 \\
\times 10^{7}\end{array}$ & $\begin{array}{l}1.49 x \\
10^{4}\end{array}$ \\
\hline $\begin{array}{l}\text { Heaven's } \\
\text { Gate }\end{array}$ & Owyhee & 117.7075 & 42.9808 & 0.8 & $\begin{array}{l}\text { Complex } \\
\text { rotational } \\
\text { failure }\end{array}$ & $\begin{array}{l}\text { Boulder bar } \\
\text { downstream }\end{array}$ & 22951 & 52 & 344 & 460 & $\begin{array}{l}8.02 \\
\times 10^{7}\end{array}$ & $\begin{array}{l}2.97 x \\
10^{4}\end{array}$ \\
\hline Artillery & Owyhee & 117.6989 & 43.0271 & 1.1 & $\begin{array}{l}\text { Complex } \\
\text { rotational } \\
\text { failure }\end{array}$ & $\begin{array}{l}\text { Boulder bar } \\
\text { downstream }\end{array}$ & 23072 & 37 & 341 & 200 & $\begin{array}{l}2.32 \\
\times 10^{7}\end{array}$ & $\begin{array}{l}1.26 x \\
10^{4}\end{array}$ \\
\hline $\begin{array}{l}\text { West } \\
\text { Springs } \\
\text { Greeley }\end{array}$ & Owyhee & 117.5658 & 43.2053 & 7.9 & Earth flow & $\begin{array}{l}\text { Possible } \\
\text { related } \\
\text { terraces } \\
\text { upstream }\end{array}$ & 25145 & 28 & 300 & $\begin{array}{l}192 \\
0\end{array}$ & $\begin{array}{l}2.39 \\
\times 10^{7}\end{array}$ & $\begin{array}{l}8.21 x \\
10^{3}\end{array}$ \\
\hline
\end{tabular}




\begin{tabular}{|c|c|c|c|c|c|c|c|c|c|c|c|c|}
\hline $\begin{array}{l}\text { East } \\
\text { Springs } \\
\text { Greeley }\end{array}$ & Owyhee & 117.5478 & 43.2071 & 2.9 & Earth flow & $\begin{array}{l}\text { Boulder bar } \\
\text { downstream, } \\
\text { possible } \\
\text { related } \\
\text { terraces } \\
\text { upstream }\end{array}$ & 25157 & 36 & 219 & 710 & $\begin{array}{l}2.68 \\
\times 10^{7}\end{array}$ & $\begin{array}{l}7.37 x \\
10^{3}\end{array}$ \\
\hline
\end{tabular}

${ }^{\mathrm{a}} \mathrm{ND}=$ no data 